\title{
Role of mitochondrial function in the invasiveness of human colon cancer cells
}

\author{
CHEN-SUNG LIN ${ }^{1,2,6,7^{*}}$, LI-TZU LIU ${ }^{3,4^{*}}$, LIANG-HUNG OU ${ }^{7}$, SIAO-CIAN PAN ${ }^{3,5,8}$, \\ CHIA-I LIN ${ }^{9}$ and YAU-HUEI WEI ${ }^{1-3,5,8}$
}

\begin{abstract}
${ }^{1}$ Faculty of Medicine, ${ }^{2}$ Institute of Clinical Medicine and ${ }^{3}$ Institute of Biochemistry and Molecular Biology, National Yang-Ming University, Taipei; ${ }^{4}$ Department of Post Baccalaureate Medicine, Kaohsiung Medical University, Kaohsiung; ${ }^{5}$ Department of Medicine, Mackay Medical College, New Taipei City;

${ }^{6}$ Division of Thoracic Surgery, Feng-Yuan Hospital, Ministry of Health and Welfare, Taichung;

${ }^{7}$ Division of General Surgery, Taipei Hospital, Ministry of Health and Welfare, New Taipei City;

${ }^{8}$ Center for Mitochondrial Medicine and Free Radical Research, Changhua Christian Hospital, Changhua City;

${ }^{9}$ Department of Pathology, Taipei Hospital, Ministry of Health and Welfare, New Taipei City, Taiwan, R.O.C.
\end{abstract}

Received February 17, 2017; Accepted October 2, 2017

DOI: $10.3892 /$ or.2017.6087

\begin{abstract}
We investigated the role of mitochondrial function in the invasiveness of human colorectal cancer (CRC) cell lines, using paired primary SW480 and metastatic SW620 cells, and appraised the clinical relevance of the alteration of mtDNA copy number in 33 pairs of CRC specimens after surgical resection. Suppression of mitochondrial function was achieved by the exposure of cells to oligomycin A (OA) or by knockdown of mitochondrial transcriptional factor A (TFAM) to evaluate their effects on energy metabolism, reactive oxygen species, protein expression levels of epithelialmesenchymal transition (EMT) markers and invasive activity of CRC cells. We found that SW620 cells expressed higher levels of TFAM and mitochondrial DNA (mtDNA)-encoded NADH dehydrogenase subunit 6 (ND6) and cytochrome $c$ oxidase subunit II (COX-II) and nuclear DNA-encoded NADH ubiquinone oxidoreductase subunit A9 (NDUFA9), iron-sulfur protein subunit $\mathrm{B}$ of succinate dehydrogenase (SDHB), ubiquinol-cytochrome $c$ reductase core protein I/II (UQCRC1/2) and cytochrome $c$ oxidase subunit IV (COX-IV) when compared with the SW480 cells. The mtDNA copy number, ADP-triggered oxygen consumption rate (OCR) and respiratory control ratio (RCR) of succinate-supported
\end{abstract}

Correspondence to: Professor Yau-Huei Wei, Center for Mitochondrial Medicine and Free Radical Research, Changhua Christian Hospital, Changhua City 500, Taiwan, R.O.C.

E-mail: yhweibabi@gmail.com

*Contributed equally

Key words: colorectal cancer, invasiveness, lactate production rate, mitochondrial biogenesis, mitochondrial DNA, mitochondrial transcriptional factor A, oxygen consumption rate, reactive oxygen species, Warburg effect respiration in the SW620 cells were higher than those noted in the SW480 cells. The intracellular levels of $\mathrm{H}_{2} \mathrm{O}_{2}$ and $\mathrm{O}_{2}{ }^{-}$ in the SW620 cells were lower than levels noted in the SW480 cells. Moreover, SW620 cells displayed lower protein levels of hexokinase II (HK-II), glucose 6-phosphate isomerase (GPI) and lactate dehydrogenase (LDH), and lower lactate production rate, and expressed higher levels of EMT markers $\mathrm{N}$-cadherin, vimentin and Snail, and showed higher Transwell migration and invasion activities as compared with the SW480 cells. After OA treatment, SW620 cells exhibited a decrease in OCR and RCR of succinate-supported respiration, an increase in lactate production rate and intracellular levels of $\mathrm{H}_{2} \mathrm{O}_{2}$ and $\mathrm{O}_{2}^{-*}$. Moreover, the level of vimentin and Transwell migration activity of the SW620 cells were decreased. After TFAM knockdown, the protein levels of TFAM, ND6 and COX-II, and mtDNA copy number, OCR and RCR of succinate-supported respiration in the SW620-KD\#4 and SW620-KD\#5 cells were all lower than those noted in the SW620-Control cells. By contrast, the protein level of HK-II, lactate production rate, the intracellular levels of $\mathrm{H}_{2} \mathrm{O}_{2}$ and $\mathrm{O}_{2}{ }^{-}$in the SW620-KD\#4 and SW620-KD\#5 cells were all higher than those noted in the SW620-Control cells. Subsequently, both SW620-KD\#4 and SW620-KD\#5 cells had lower Transwell invasion activity than did the SW620-Control cells. Furthermore, we found that deeper invasion $(\mathrm{P}=0.025)$ and longer tumor length $(\mathrm{P}=0.069)$ were associated with higher mtDNA copy ratios in the 33 pairs of CRC specimens obtained from surgical resection. Taken together, we conclude that higher mtDNA copy number and mitochondrial function may confer an invasive advantage to CRCs.

\section{Introduction}

Colorectal cancer (CRC) is one of the leading causes of cancerrelated deaths in Taiwan and worldwide (Health Promotion Administration, the Ministry of Health and Welfare, Taiwan: http://www.hpa.gov.tw/English/Index.aspx; Center for Disease 
Control and Prevention, USA: http://www.cdc.gov/cancer/ colorectal/). Due to the invasive property, CRC may cause direct tissue invasion, regional lymph node involvement or distant organ metastasis, which culminates in incurable or life-threatening disease (1). With regard to the regulation of CRC invasiveness, most studies have focused on oncogenes or tumor-suppressor genes. However, the role of mitochondria in CRC remains unclear $(2,3)$.

In the early 20th century, Dr Warburg described that human cancers display an avid glucose uptake with profound lactate production even under a sufficient oxygen supply (4). He proposed that respiratory enzymes are impaired or suppressed in human cancers. Such a phenomenon was termed the Warburg effect, and the enhanced glycolysis was supposed to compensate for the 'defective or suppressed mitochondria' to produce a sufficient amount of $\operatorname{ATP}(5,6)$.

Mitochondria are the major organelles responsible for ATP production through the Krebs cycle and electron transport chain (ETC) that consists of respiratory enzyme complexes I, II, III, IV and V (7). Mitochondria have their own mtDNA copies packed in the nucleoid. In contrast to one set of nuclear DNA (nDNA) in the nucleus, there are several nucleoids distributed in the cytoplasmic mitochondria. The nucleoid is an efficient and constitutional unit of the mitochondrial network $(8,9)$. Except that 4 polypeptides of complex II are all encoded by nDNA, 90 polypeptides constituting the respiratory enzyme complexes I, III, IV and V are encoded by the nDNA and mtDNA cooperatively (10). As a result, delicate regulation of mtDNA plays a pivotal role in the maintenance of mitochondrial biogenesis. Mitochondrial biogenesis or mitochondrial function is correlated positively with the amount of mtDNA, and a higher mtDNA copy number indicates higher mitochondrial function (11). Several DNA-binding proteins are involved in the replication or transcription of mtDNA, and the mitochondrial transcriptional factor A (TFAM) is the unique one that regulates mtDNA replication and transcription in the nucleoid $(12,13)$.

During the past 20 years, alterations in mtDNA and mitochondrial function have been evaluated in many human cancers $(2,14,15)$. Various studies have demonstrated an increase in mitochondrial function or mtDNA copy number during carcinogenesis or progression of human cancers, including skin $(16,17)$, head and neck $(18)$, breast $(19,20)$ and esophageal cancer $(21,22)$. On the contrary, other studies have shown suppressed or impaired mitochondrial function with amplified glycolysis or a decrease in mtDNA copy number during carcinogenesis or progression of cancers (23), which include lung $(24,25)$, renal $(26,27)$, gastric (28) and hepatic cancer $(29,30)$. Since TFAM plays a key role in the regulation of mitochondrial biogenesis, its involvement in human cancers has been appraised in endometrial, prostate and bladder cancer (31-33). By means of TFAM knockdown to suppress mitochondrial function, we demonstrated a decrease in the invasive activity in an esophageal squamous cell carcinoma cell line, but an increase in invasive activity in a renal cell carcinoma cell line $(22,27)$. In light of these findings, the role of mitochondria in human cancers deserves further study.

Likewise, the role of mitochondrial function in human CRCs has remained speculative and an appraisal of the role of mitochondrial function in human CRCs is clinically relevant. In the present study, we investigated the effects of the suppression of mitochondrial function, either induced by oligomycin A (OA) treatment or by TFAM knockdown, on the invasiveness of CRC cell lines (34). The alterations in mtDNA copy number, metabolic profiles, intracellular ROS levels and expression of EMT markers were also examined. However, we analyzed the mtDNA copy numbers in 33 pairs of specimens from CRC patients. We believe that the findings of the present study may help us to better understand the pathophysiology of human $\mathrm{CRC}$ from the viewpoint of mitochondrial biology.

\section{Materials and methods}

CRC cell lines, cell viability and caspase 3 activity. Paired CRC cell lines, the primary SW480 (Amerian Type Culture Collection, ATCC, Manassas, VA, USA; CCL-228) and metastatic SW620 (ATCC, CCL-227), were used in the present study. They were established from the same CRC patient at different disease stages, i.e., SW480 from the primary adenocarcinoma at age of 50, Dukes' type B; and SW620 from the metastatic lymph node at age of 51 during recurrence, Dukes' type $\mathrm{C}(34,35)$. According to the gene analysis, their alterations were mainly those involved in the regulation of transcription, cell cycle control and division, cell signaling and cell adhesion as well as cell metabolism (36). As a result, they are suitable for evaluation of the role of mitochondrial function in CRC invasion.

The culture medium was composed of Roswell Park Memorial Institute-1640 (RPMI-1640) with 10\% fetal bovine serum (FBS), $2 \mathrm{~g} / 1 \mathrm{NaHCO}_{3}$ and antibiotics including $100 \mathrm{U} / \mathrm{ml}$ penicillin $\mathrm{G}, 100 \mu \mathrm{g} / \mathrm{ml}$ streptomycin sulfate and $0.25 \mu \mathrm{g} / \mathrm{ml}$ amphotericin B (37).

$\mathrm{OA}$, an inhibitor of respiratory enzyme complex V, was purchased from Merck Inc. (Darmstadt, Germany) to suppress mitochondrial function in the present study. The optimal concentration and duration of OA treatment $(10$ and $20 \mu \mathrm{g} / \mathrm{ml}$ for 24 or $48 \mathrm{~h}$ ) were titrated and modified according to the assays for cell viability and caspase 3 activity as previously reported (38-40).

A total of 5,000 SW620 cells suspended in $100 \mu 1$ of growth medium were seeded on a 96-well plastic reader plate (Corning Glass Works, Corning, NY, USA) for $24 \mathrm{~h}$ to achieve the steady state. The culture medium was then changed to new ones with and without addition of OA (10 and $20 \mu \mathrm{g} / \mathrm{ml}$ ) for 24 and $48 \mathrm{~h}$, respectively. After incubation for 24 or $48 \mathrm{~h}$ at $37^{\circ} \mathrm{C}$, an additional $200 \mu \mathrm{l}$ of $1 \mathrm{X}$ AlamarBlue ${ }^{\mathrm{TM}}$ reagent (Invitrogen) was added to the cells and further incubated for $1.5 \mathrm{~h}$. The fluorescence intensity was measured by the Victor $2^{\mathrm{TM}} 1420$ Multilabel Counter (Perkin-Elmer Life Sciences, Waltham, MA, USA) on a reader plate set at the excitation wavelength of $538 \mathrm{~nm}$ and emission wavelength of $590 \mathrm{~nm}$ (22). The cell viability was calculated by the ratio between the fluorescence intensity of cells treated with OA to those without OA. Each experiment was repeated using 3 batches of culture cells $(n=3)$. The data are presented as mean \pm SD.

Caspase 3 activity was assayed by the EnzChek Caspase-3 Assay kit \#2 (Molecular Probes, Eugene, OR, USA) (41). An aliquot of $50 \mu \mathrm{l}$ cellular protein lysate or lysis buffer (as blank control) was mixed with $50 \mu 1$ of substrate working buffer (20 mM PIPES, 4 mM EDTA, 0.2\% CHAPS, 10 mM dithio- 
threitol and $50 \mu \mathrm{M}$ Z-DEVD-R110 substrate, $\mathrm{pH}$ 7.4) at room temperature for $30 \mathrm{~min}$. Due to the recognition of the specific amino acid sequence Asp-Glu-Val-Asp (DEVD) by caspase 3, the linkage between DEVD and fluorescent Rhodamine 110 (R110) was broken to emit fluorescence. The excitation wavelength was set at $485 \mathrm{~nm}$, and the intensity of the emitted fluorescence at $510 \mathrm{~nm}$ was recorded by the Victor $2^{\mathrm{TM}} 1420$ Multilabel Counter on a reader plate. In this experiment, $100 \mathrm{nM}$ staurosporinex (STS) was added to the cells and incubated for $6 \mathrm{~h}$ prior to protein purification to induce apoptosis as the positive control. The fluorescence intensity was normalized by the protein concentration in each group to assess the relative caspase 3 activity. The relative caspase 3 activity of SW620 cell without treatment with OA was defined as $100 \%$. Each experiment was repeated using 3 batches of culture cells $(n=3)$. Data are presented as mean \pm SD.

Transfection for TFAM knockdown. Two small hairpin RNA (shRNA) oligonucleotides, constructed into pLKO.1 DNA backbone, respectively, were supplied by the National RNAi Core Facility of Academia Sinica in Taiwan (http://rnai. genmed.sinica.edu.tw/index.asp). They were named as vector- $\# 4$ and $-\# 5$, and were used to knock down TFAM expression $(22,27)$. The oligonucleotide sequences against TFAM mRNA of vector-\#4 and -\#5 were: 5'-CGTTTATGT AGCTGAAAGATT-3' and 5'-GCAGATTTAAAGAACAGC TAA-3', respectively; the oligonucleotide 5'-CAAATCACAGA ATCGTCGTAT-3', specific to the gene coding for luciferase (Luc), was constructed as the control vector. With the facilitation of Lipofectamine 2000, $4 \mu \mathrm{g}$ of vector DNA was transfected into the SW620 cells $\left(10^{6}\right.$ cells in a 6 -well plate $)$ (42). The culture medium containing $1 \mu \mathrm{g} / \mathrm{ml}$ puromycin (lethal dose for SW620) was used for clone selection. The SW620 cells harboring the control vector, knockdown vector-\#4 and -\#5 were named SW620-Control, SW620-KD\#4 and SW620-KD\#5, respectively.

Oxygen consumption rate and respiratory control ratio. The cellular oxygen consumption rate (OCR, $\mathrm{nmol} / \mathrm{min} / 10^{6}$ cells) was measured by a 782 Oxygen Meter (Strathkelvin Instruments, Scotland, UK) at $37^{\circ} \mathrm{C}$ under a circulating water system $(22,43)$. During the steady state $\left(10^{6}\right.$ cells in the assay mixture), digitonin was added at a final concentration of $0.0006 \%$ to pierce the plasma membrane and enable direct exposure of the respiratory enzyme complexes to the substrates and inhibitors. Succinate and ADP were added sequentially to final concentrations of 10 and $1 \mathrm{mM}$, to measure the OCR-Succinate and OCR-ADP values, respectively. The respiratory control ratio (RCR) was defined and calculated as the ratio between OCR-ADP to OCR-Succinate to assess the integrity of the structure and function of mitochondria $(44,45)$. Each experiment was repeated using three batches of cultured cells $(n=3)$.

Total intracellular ATP content. The intracellular ATP content (fmol/cell) was measured using the ATP Bioluminescent Somatic Cell Assay kit (Sigma-Aldrich) (22). Under steady state, cells were trypsinized, re-suspended and mixed with Somatic Cell Releasing Reagent, and then transferred to a black OptiPlate-96F 96-well reader plate (Packard Biosciences, Perkin-Elmer) containing the ATP assay mixture. The luminescence intensity was measured using the Victor2 ${ }^{\mathrm{TM}} 1420$ Multilabel Counter and was normalized by the cell number. Each experiment was repeated using three batches of cultured cells $(n=3)$.

Lactate production rate. Under steady state, cells were washed with phosphate-buffered saline (PBS) and added to fresh growth medium in an incubator at $37^{\circ} \mathrm{C}$ for $4 \mathrm{~h}$. An aliquot of $10 \mu \mathrm{l}$ medium was then transferred to a $96-$-well plate and mixed with the Lactate Reagent (Trinity Biotech Plc., Bray, Ireland). The absorbance at $540 \mathrm{~nm}$ was measured on an ELISA reader (BioTek PowerWaveX 340; Boston Laboratory Equipment, Boston, MA, USA) and was normalized by the cell number to calculate the lactate production rate $\left(\mathrm{ng} / \mathrm{h} / 10^{4}\right.$ cells) $(22,43)$. Each experiment was repeated using three batches of cultured cells $(n=3)$.

Transwell migration and invasion assays. Transwell migration or invasion activity was assayed using Millicell hanging cell culture inserts harboring $8-\mu \mathrm{m}$ pores (Millipore, Bedford, MA, USA) coated with or without Matrigel placed into a 24-well plate $(22,27)$. Growth medium $(400 \mu \mathrm{l})$ containing RPMI-1640 plus $10 \%$ FBS was added to the 24 -well plate, and $5 \times 10^{4}$ cells suspended in $150 \mu 1$ of growth medium containing RPMI-1640 plus 1\% FBS were seeded in the insert. After incubation for $24 \mathrm{~h}$, cells were removed from the upper surface of the membranes of the insert with a cotton swab. Cells that migrated or invaded to the lower surface were fixed with methanol for $20 \mathrm{~min}$ and stained with Hoechst 33342 ( $1 \mu \mathrm{g} / \mathrm{ml}$; Sigma-Aldrich). Three random areas under a light microscope (magnification, $\mathrm{x} 40$ ) were selected to count the migrated/invaded cells and to obtain the average cell number (cells/field) $(22,27)$. Each experiment was repeated using three batches of cultured cells $(n=3)$.

Intracellular ROS levels. The intracellular level of $\mathrm{H}_{2} \mathrm{O}_{2}$ was determined as previously described (46). Approximately $3 \times 10^{6}$ cells were seeded in a $6-\mathrm{cm}$ dish, and $2 \mathrm{ml}$ of medium containing 2'-7'-dichlorofluorescin diacetate (DCFH-DA; $40 \mu \mathrm{M}$ ) was added and incubated at $37^{\circ} \mathrm{C}$ for $20 \mathrm{~min}$. After trypsinization, cells were subjected to analysis on a flow cytometer (Model EPICS XL-MCL, Beckman-Coulter, Miami, FL, USA). The excitation wavelength was set at $488 \mathrm{~nm}$, and the intensity of emitted fluorescence of 10,000 cells at $525 \mathrm{~nm}$ was recorded. The data were analyzed by EXPO32 software (Beckman-Coulter). Each experiment was repeated using three batches of cultured cells $(n=3)$.

The intracellular levels of $\mathrm{O}_{2}^{-\bullet}$ were also determined as previously described (46). Approximately $3 \times 10^{6}$ cells were seeded in a $6-\mathrm{cm}$ dish, and $2 \mathrm{ml}$ of medium containing hydroethidine (HE; $5 \mu \mathrm{M}$ ) was added and incubated at $37^{\circ} \mathrm{C}$ for $20 \mathrm{~min}$. After trypsinization, cells were subjected to analysis on a flow cytometer (Model EPICS XL-MCL). The excitation wavelength was set at $488 \mathrm{~nm}$ and the intensity of emitted fluorescence of 10,000 cells at $580 \mathrm{~nm}$ was recorded. The data were analyzed using EXPO32 software. Each experiment was repeated using three batches of cultured cells $(n=3)$.

Preparation of cellular DNA, RNA and proteins. Extraction of cellular DNA and RNA and its reverse-transcription to cDNA 
Table I. Summary of the analyzed target genes and sequences of the primers used to amplify the indicated genes.

DNA
mtDNA $^{\mathrm{a}}$
nDNA $^{\mathrm{b}}$
Messenger RNA (mRNA)
Reference gene
$\beta$-actin
Target genes
PGC-1 $\alpha$
TFAM
HK-II
GPI
PFK
LDH

\author{
CACCCAAGAACAGGGTTTGT \\ TAGAGGGACAAGTGGCGTTC
}

CCAACCGTGAAAAGATGACC

TGAGAGGGCCAAGCAAAG

CAACTACCCATATTTAAAGCTCAGAA CCCTGCCACCAGACTAAACT GGAAGGGTCTGCATCACAAG AGGAGGGGAAGGGCATCT GCAGATTTGGCAGAGAGTATAATG

\author{
TGGCCATGGGTATGTTGTTAA \\ CGCTGAGCCAGTCAGTGT
}

${ }^{a}$ The analyzed region of mtDNA was the tRNA ${ }^{\text {Leu (UUR) }}$ gene. ${ }^{b}$ The analyzed region of nDNA was the $18 \mathrm{~S}$ rRNA gene. mtDNA, mitochondrial DNA; nDNA, nuclear DNA; PGC-1 $\alpha$, peroxisome proliferator-activated receptor $\gamma$ coactivator 1- $\alpha$; TFAM, mitochondrial transcriptional factor A; HK-II, hexokinase II; GPI, glucose 6-phosphate isomerase; PFK, phosphofructokinase; LDH, lactate dehydrogenase.

as well as protein purification were performed as previously described $(27,47,48)$.

Collection of clinical samples and DNA extraction. A total of 33 CRC patients who had received surgical resection at Taipei Hospital, Ministry of Health and Welfare (New Taipei City, Taiwan) were retrospectively collected and their pathological slides were reviewed by an experienced pathologist. Representative tumor foci without tumor necrosis and without lymphocyte infiltration were identified, and thin slices $\sim 5-\mu \mathrm{m}$ in thickness from paraffin-embedded tissue blocks were prepared for DNA extraction. Simultaneously, the paired non-cancerous regions were also collected as control. After de-waxing and re-hydration processes, tissue samples were mixed with $500 \mu 1$ of the DNA extraction solution (QuickExtract; Epicenter, Madison, WI, USA) to extract total cellular DNA at $65^{\circ} \mathrm{C}$ for $3 \mathrm{~h}$ as previously described $(20,21)$. The DNA samples were kept at $-20^{\circ} \mathrm{C}$ until use.

Determination of relative mtDNA copy number and $m R N A$ expression levels. Quantitative polymerase chain reaction (qPCR) using SYBR-Green I (Roche Applied Science, Penzberg, Germany) was employed to determine the threshold cycle $(\mathrm{Ct})$ for the calculation of relative mtDNA copy number and relative mRNA expression levels of specific genes by the $2^{-\Delta \Delta C t}$ method (47-49). The mtDNA copy number is defined as the total copies of tRNA ${ }^{\text {Leu (UUR) }}$ (mtDNA) relative to the total copies of 18S rRNA (nDNA). The mRNA expression level was defined as the total cDNA copies of the gene of interest relative to the total cDNA copies of $18 \mathrm{~S}$ rRNA.

For analysis of the cellular mtDNA copy number or target gene mRNA expression level in the SW620 and SW480 cells, the value of SW480 was taken as 1.00. Each experiment was repeated using three batches of cultured cells $(n=3)$. For analysis of clinical samples, the 143B cell DNA (1 ng/ $\mu \mathrm{l})$ was loaded as a control in each run of qPCR and the mtDNA copy number of 143B cells was adjusted as 1.00. Furthermore, we defined mtDNA copy ratio as the mtDNA copy number of the tumor part divided by the mtDNA of the non-tumor part for each CRC patient. The oligonucleotide sequences of primers are summarized in Table I $(22,27,48)$.

Determination of relative protein expression levels. The relative protein expression levels of the genes of interest were determined using western blotting. An aliquot of $50 \mu \mathrm{g}$ of total cellular proteins was separated on a $10 \%$ sodium dodecyl sulfate-polyacrylamide gel electrophoresis (SDS-PAGE), and then blotted onto a piece of BioTrace ${ }^{\mathrm{TM}}$ polyvinylidene difluoride (PVDF) membrane (Pall Corporation, Pensacola, FL, USA). Non-specific bindings were blocked with 5\% skimmed milk in a Tris-buffered saline Tween-20 (TBST) buffer (50 mM Tris- $\mathrm{HCl}, 150 \mathrm{mM} \mathrm{NaCl}$ and $0.1 \%$ Tween-20, $\mathrm{pH}$ 7.4). The membrane was subjected to specific primary antibodies against target proteins, as listed in Table II, and was incubated for $16 \mathrm{~h}$ at $4^{\circ} \mathrm{C}(22,50)$. $\beta$-actin was used as the internal control. The membrane was then incubated with a horseradish peroxidase (HRP)-conjugated secondary antibody for $1 \mathrm{~h}$ at room temperature, the protein band was visualized on X-ray film (Fujifilm, Tokyo, Japan) using enhanced chemiluminescence (ECL) reagents (GE Healthcare, Chalfont, UK). The band density was scanned by a densitometer to calculate the relative protein expression levels. Each experiment was repeated using three batches of cultured cells $(n=3)$.

Statistical analysis. The continuous variables between two or among three or more independent groups were analyzed using Student's t-test or Mann-Whitey U test (two groups)/or the one-way analysis of variance (ANOVA) or Kruskal-Wallis $\mathrm{H}$ test (three or more groups) when appropriate. Significant difference was considered at a P-value $<0.05$. 
Table II. Summary of the primary antibodies and their dilution titers and suppliers used in the present study.

\begin{tabular}{|c|c|c|c|}
\hline \multicolumn{2}{|c|}{ Primary antibody } & \multirow{2}{*}{$\begin{array}{l}\text { Titer } \\
1: 1,000\end{array}$} & \multirow{2}{*}{$\frac{\text { Supplier }}{\text { Molecular Probes, Eugene, OR, USA }}$} \\
\hline ND6 & (Subunit of complex I, mtDNA encoded) & & \\
\hline NDUFA9 & (Subunit of complex I, nDNA encoded) & $1: 1,000$ & Molecular Probes, Eugene, OR, USA \\
\hline SDHA & (Subunit of complex II, nDNA encoded) & $1: 1,000$ & Molecular Probes, Eugene, OR, USA \\
\hline SDHB & (Subunit of complex II, nDNA encoded) & $1: 2,000$ & Molecular Probes, Eugene, OR, USA \\
\hline UQCRC1 & (Subunit of complex III, nDNA encoded) & $1: 2,000$ & Molecular Probes, Eugene, OR, USA \\
\hline UQCRC2 & (Subunit of complex III, nDNA encoded) & $1: 2,000$ & Molecular Probes, Eugene, OR, USA \\
\hline COX-II & (Subunit of complex IV, mtDNA encoded) & $1: 1,000$ & Molecular Probes, Eugene, OR, USA \\
\hline COX-IV & (Subunit of complex IV, nDNA encoded) & $1: 1,000$ & Molecular Probes, Eugene, OR, USA \\
\hline GPI & & $1: 1,000$ & Santa Cruz Biotechnology, Santa Cruz, CA, USA \\
\hline $\mathrm{LDH}$ & & $1: 5,000$ & Santa Cruz Biotechnology, Santa Cruz, CA, USA \\
\hline $\mathrm{PDH}$ & & $1: 1,000$ & Santa Cruz Biotechnology, Santa Cruz, CA, USA \\
\hline HK-II & & $1: 1,000$ & Merck Millipore, Darmstadt, Germany \\
\hline E-cadherin & & $1: 1,000$ & Cell Signaling, Danvers, MA, USA \\
\hline N-cadherin & & $1: 1,000$ & $\begin{array}{l}\text { BD (Becton-Dickinson and Company, } \\
\text { Franklin Lakes, NJ, USA) }\end{array}$ \\
\hline Vimentin & & $1: 1,000$ & Sigma-Aldrich, St. Louis, MO, USA \\
\hline Snail & & $1: 1,000$ & Abcam, Cambridge, MA, USA \\
\hline TFAM & & $1: 1,000$ & Santa Cruz Biotechnology, Santa Cruz, CA, USA \\
\hline$\beta$-actin & & $1: 10,000$ & Merck Millipore, Darmstadt, Germany \\
\hline
\end{tabular}

ND6, mtDNA-encoded NADH dehydrogenase subunit 6; NDUFA9, NADH ubiquinone oxidoreductase subunit A9; SDHA, succinate dehydrogenase complex flavoprotein subunit A; SDHB, succinate dehydrogenase complex iron-sulfur subunit B; UQCRC1, ubiquinol-cytochrome $c$ reductase core protein I; UQCRC2, ubiquinol-cytochrome $c$ reductase core protein II; COX-II, mtDNA-encoded cytochrome $c$ oxidase subunit II; COX-IV, cytochrome $c$ oxidase subunit IV; GPI, glucose-6-phosphate isomerase; LDH, lactate dehydrogenase; PDH, pyruvate dehydrogenase; HK-II, hexokinase II; TFAM, mitochondrial transcription factor A.

\section{Results}

Difference in metabolic profiles, ROS levels and invasive activity between SW480 and SW620 CRC cell lines. The metastatic SW620 cells exhibited a higher percentage of fibroblast-like morphology than did primary SW480 cells under light microscopy (Fig. 1). Regarding the metabolic profiles of mitochondria (Fig. 1 and Table III), SW620 cells had a higher mtDNA copy number $(2.05 \pm 0.57$ vs. $1.00 \pm 0.00$, $\mathrm{P}=0.006)$, higher ADP-stimulated OCR $(3.41 \pm 0.02$ vs. $2.94 \pm 0.09, \mathrm{P}=0.020)$ and higher respiratory control ratio $(\mathrm{RCR}$, $1.90 \pm 0.03$ vs. $1.57 \pm 0.06 ; \mathrm{P}=0.018)$ of succinate-supported respiration rate than did SW480 cells. SW620 cells had higher mRNA and protein expression levels of mitochondrial biogenesis-related proteins including the mRNAs for peroxisome proliferator-activated receptor $\gamma$ coactivator $1-\alpha$ (PGC-1 $\alpha$, $6.90 \pm 0.71$ vs. $1.00 \pm 0.00, \mathrm{P}=0.007)$ and TFAM $(2.58 \pm 0.20$ vs. $1.00 \pm 0.00, \mathrm{P}<0.001$ ) (Table III), and proteins for TFAM $(4.01 \pm 0.48$ vs. $1.00 \pm 0.00, \mathrm{P}<0.001)$ and pyruvate dehydrogenase (PDH) $(1.56 \pm 0.11$ vs. $1.00 \pm 0.00, \mathrm{P}=0.001)$ (Fig. 1) than did SW480 cells. SW620 cells also expressed higher protein levels of mitochondrial respiratory enzyme complexes including mtDNA-encoded NADH dehydrogenase subunit 6 (ND6, subunit of complex I, $1.63 \pm 0.13$ vs. $1.00 \pm 0.00, \mathrm{P}=0.001$ ) and cytochrome $c$ oxidase subunit II (COX-II, subunit of complex IV, $1.75 \pm 0.07$ vs. $1.00 \pm 0.00, \mathrm{P}=0.004$ ) (Fig. 1 ), and nDNA-encoded NADH ubiquinone oxidoreductase subunit A9
(NDUFA9; subunit of complex I, $1.60 \pm 0.24$ vs. $1.00 \pm 0.00$, $\mathrm{P}=0.013$ ), iron-sulfur protein subunit $\mathrm{B}$ of succinate dehydrogenase (SDHB, subunit of complex II, $2.55 \pm 0.67$ vs. $1.00 \pm 0.00$, $\mathrm{P}=0.016$ ), ubiquinol-cytochrome $c$ reductase core protein I (UQCRC1, subunit of complex III, $1.66 \pm 0.35$ vs. $1.00 \pm 0.00$, $\mathrm{P}=0.032$ ) and UQCRC2 (subunit of complex III, $2.01 \pm 0.44$ vs. $1.00 \pm 0.00, \mathrm{P}=0.084)$ and cytochrome $c$ oxidase subunit IV (COX-IV, subunit of complex IV, $1.86 \pm 0.23$ vs. $1.00 \pm 0.00$, $\mathrm{P}=0.033$ ) (Fig. 1) when compared with the SW480 cells.

Regarding the metabolic profile of glycolysis (Fig. 1 and Table III), the SW620 cells showed lower expression levels of glycolytic enzymes, including mRNA levels of hexokinase II (HK-II, $0.73 \pm 0.06$ vs. $1.00 \pm 0.00, P=0.002$ ), glucose 6 -phosphate isomerase (GPI; $0.74 \pm 0.07$ vs. $1.00 \pm 0.00, \mathrm{P}=0.003$ ), phosphofructokinase (PFK; $0.71 \pm 0.03$ vs. $1.00 \pm 0.00$, $\mathrm{P}<0.001)$ and lactate dehydrogenase $(\mathrm{LDH} ; 0.49 \pm 0.01$ vs. $1.00 \pm 0.00, \mathrm{P}<0.001)$ (Table III) as well as protein levels of HK-II $(0.43 \pm 0.10$ vs. $1.00 \pm 0.00, \mathrm{P}=0.001)$, GPI $(0.48 \pm 0.06$ vs. $1.00 \pm 0.00, \mathrm{P}<0.001)$ and $\mathrm{LDH}(0.64 \pm 0.06$ vs. $1.00 \pm 0.00$, $\mathrm{P}=001)$ (Fig. 1), and a lower lactate production rate $(141.3 \pm 8.5$ vs. $204.7 \pm 13.1, \mathrm{ng} / \mathrm{h} / 10^{4}$ cells, $\mathrm{P}=0.002$ ) (Table III) when compared with the SW480 cells.

The total intracellular ATP contents of SW620 and SW480 cells did not differ $(4.71 \pm 0.12$ vs. $4.82 \pm 0.18$, fmol/cell, $\mathrm{P}=0.827$, Table III). With regard to the relative intracellular ROS levels, SW620 cells had a lower $\mathrm{H}_{2} \mathrm{O}_{2}$ level than the level noted in the SW480 cells $(0.57 \pm 0.05$ vs. $1.00 \pm 0.00, P=0.006$, Table III). The 

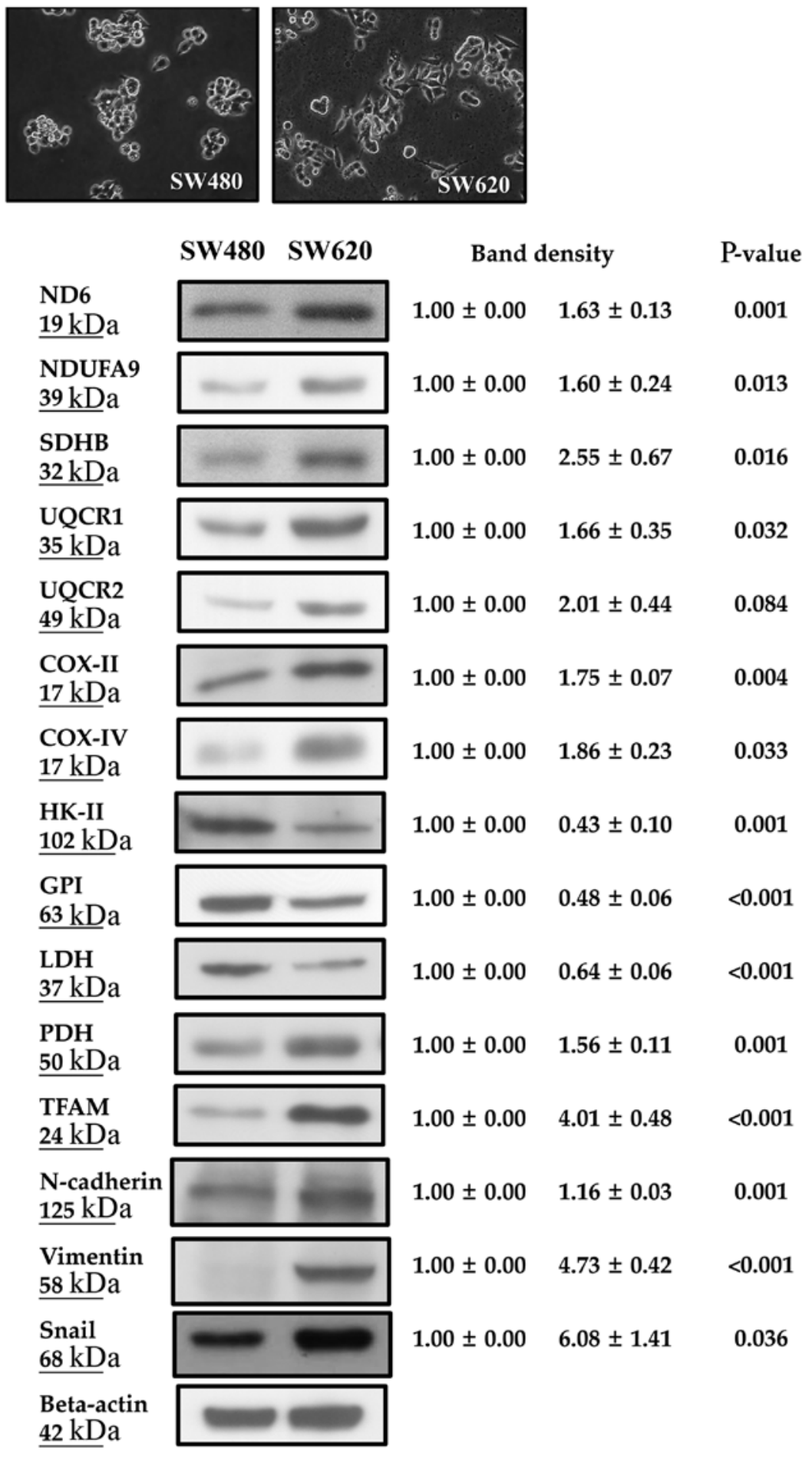

Figure 1. SW620 cells expressed a higher percentage of fibroblast-like morphology, higher levels of mitochondrial biogenesis-related proteins (ND6, NDUFA9, SDHB, UQCR1/2, COX-II/IV, PDH and TFAM), higher levels of EMT markers (N-cadherin, vimentin and Snail), but lower expression levels of glycolysisrelated enzymes (HK-II, GPI and LDH) than SW480 cells. ND6, NADH dehydrogenase subunit 6; NDUFA9, NADH ubiquinone oxidoreductase subunit A9; SDHB, iron-sulfur protein subunit B of succinate dehydrogenase; UQCRC1/2, ubiquinol-cytochrome $c$ reductase core protein I/II; COX-II, cytochrome $c$ oxidase subunit II; COX-IV, cytochrome $c$ oxidase subunit IV; PDH, pyruvate dehydrogenase; TFAM, mitochondrial transcriptional factor A; HK-II, hexokinase II; GPI, glucose 6-phosphate isomerase; LDH, lactate dehydrogenase.

SW620 cells displayed higher Transwell migration (325.6 \pm 66.8 vs. $93.1 \pm 31.1$, cells/field, $\mathrm{P}<0.001)$ and invasion $(58.6 \pm 4.4$ vs. $15.8 \pm 2.5$, cells/field, $\mathrm{P}=0.006$ ) activities (Table III and Fig. 2), and higher protein expression levels of EMT markers $\mathrm{N}$-cadherin $(1.16 \pm 0.03$ vs. $1.00 \pm 0.00, \mathrm{P}=0.001)$, vimentin $(4.73 \pm 0.42$ vs. $1.00 \pm 0.00, \mathrm{P}<0.001)$ and Snail $(6.08 \pm 1.41$ vs.
$1.00 \pm 0.00, \mathrm{P}=0.036$ ) (Fig. 1) when compared with these levels noted in the SW480 cells.

Effects of oligomycin A on cell viability, caspase 3 activity, metabolic profiles, ROS levels and invasion activity of SW620 cells. Regarding cell viability (Fig. 3A), there were 
Table III. Differences in metabolic profiles, ROS intensity and migration/invasion activities between primary SW480 and metastatic SW620 CRC cell lines.

\begin{tabular}{lccr}
\hline & \multicolumn{2}{c}{ Cell line } & \\
\cline { 2 - 3 } Parameters/variables & SW480 & SW620 & P-value $^{\mathrm{a}}$ \\
\hline mtDNA copy number & $1.00 \pm 0.00$ & $2.05 \pm 0.57$ & 0.006 \\
Oxygen consumption rate (OCR) (nmol/min/ $/ 0^{6}$ cells) & & & \\
Respiratory substrate & & & 0.508 \\
$\quad$ Succinate-supported & $1.87 \pm 0.12$ & $1.80 \pm 0.03$ & 0.020 \\
ADP-stimulated & $2.94 \pm 0.09$ & $3.41 \pm 0.02$ & 0.018 \\
Respiratory control ratio (RCR) & $1.57 \pm 0.06$ & $1.90 \pm 0.03$ & 0.002 \\
Lactate production rate (ng/h/10 cells) & $204.7 \pm 13.1$ & $141.3 \pm 8.5$ & 0.827 \\
Total intracellular ATP (fmol/cell) & $4.82 \pm 0.18$ & $4.71 \pm 0.12$ & 0.007 \\
mRNA expression level & & & $<0.001$ \\
Mitochondrial biogenesis-related proteins & & & 0.002 \\
PGC-1 $\alpha$ & $1.00 \pm 0.00$ & $6.90 \pm 0.71$ & 0.003 \\
TFAM & $1.00 \pm 0.00$ & $2.58 \pm 0.20$ & $<0.001$ \\
Glycolytic enzymes & & & $<0.001$ \\
HK-II & $1.00 \pm 0.00$ & $0.73 \pm 0.06$ & $<0.001$ \\
GPI & $1.00 \pm 0.00$ & $0.74 \pm 0.07$ & $<0.001$ \\
PFK & $1.00 \pm 0.00$ & $0.71 \pm 0.03$ & 0.006 \\
LDH & $1.00 \pm 0.00$ & $0.49 \pm 0.01$ & \\
Relative intracellular ROS level & & & \\
Hydrogen peroxide $\left(\mathrm{H}_{2} \mathrm{O}_{2}\right.$ ) & $1.00 \pm 0.00$ & $0.57 \pm 0.05$ & \\
Transwell assay (cells/field) & & $325.6 \pm 66.8$ & $58.6 \pm 4.4$ \\
Migration & $93.1 \pm 31.1$ & $15.8 \pm 2.5$ & \\
Invasion & & & \\
\hline
\end{tabular}

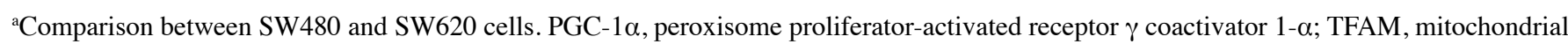
transcriptional factor A; HK-II, hexokinase II; GPI, glucose-6-phosphate isomerase; PFK, phosphofructokinase; LDH, lactate dehydrogenase; ROS, reactive oxygen species.
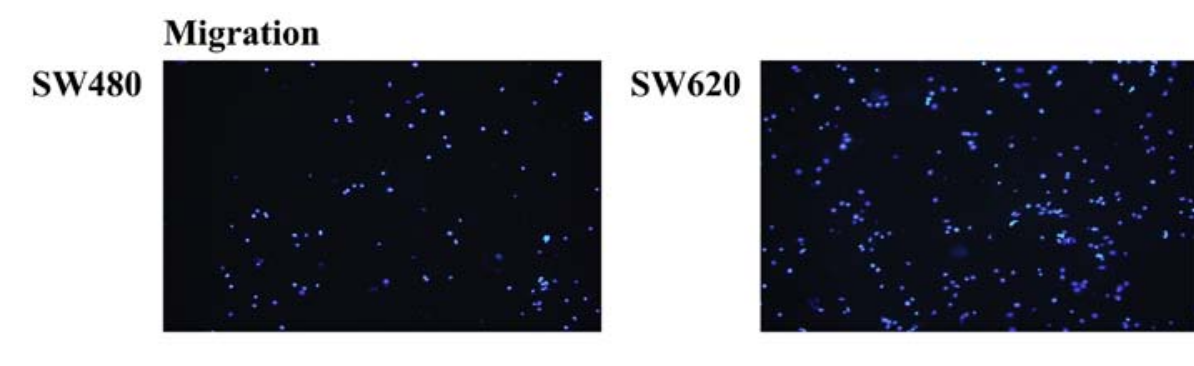

\section{Invasion}

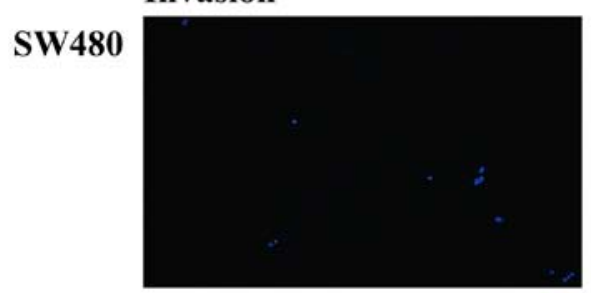

SW620

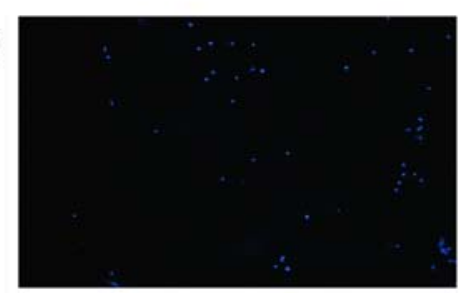

Figure 2. The Transwell migration and invasion activities of the SW620 cells were higher than those of the SW480 cells.

no obvious differences between SW620 (as control at 24 and $48 \mathrm{~h}, 100.0 \pm 0.0 \%$ ) and SW620 cells treated with OA at
$10 \mu \mathrm{g} / \mathrm{ml}$ for $24 \mathrm{~h}$ (SW620 OA-10 $24 \mathrm{~h}, 95.0 \pm 4.1 \%, \mathrm{P}=0.167)$, between SW620 $(100 \pm 0.0 \%)$ and SW620 cells treated with 
A

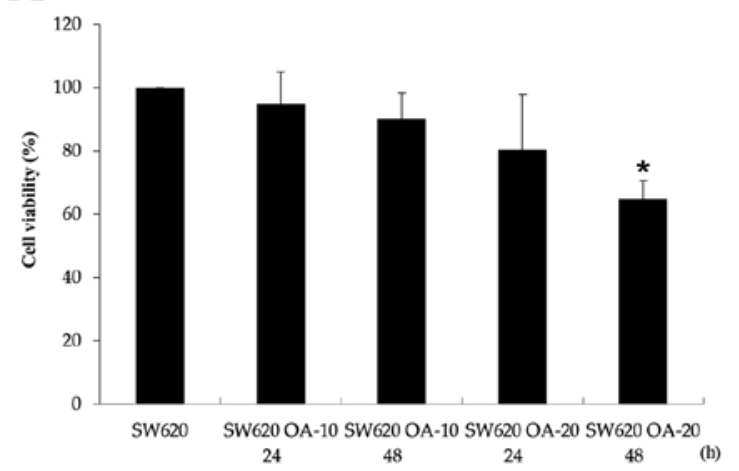

B

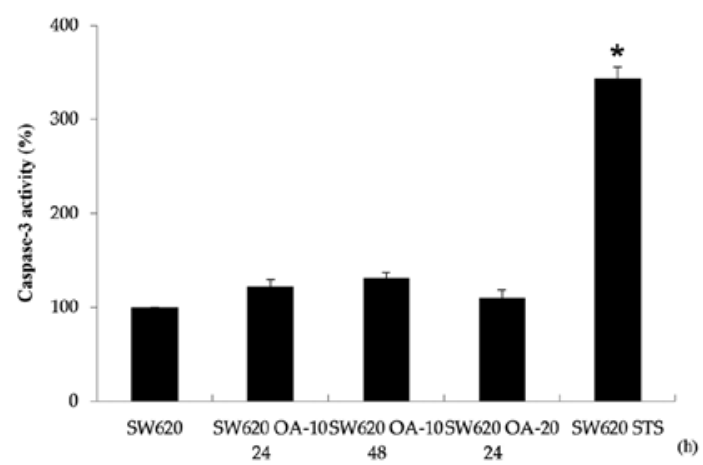

Figure 3. (A) Cell viability and (B) caspase 3 activity of SW620 and SW620 treated with 10 and $20 \mu \mathrm{g} / \mathrm{ml}$ of oligomycin A (OA) for 24 and 48 h, respectively. SW620 cells treated with $20 \mu \mathrm{g} / \mathrm{ml}$ of OA for $48 \mathrm{~h}$ had the lowest cell viability ( $\left.{ }^{*} \mathrm{P}=0.009\right)$. SW620 cells treated with STS had significantly higher caspase 3 activity $($ P $\mathrm{P}<0.05)$.

Table IV. Alterations of ADP-stimulated OCR and RCR of succinate-supported respiration and Transwell invasion activity in SW620 cells after treatment of cells with oligomycin A.

\begin{tabular}{|c|c|c|c|c|}
\hline \multirow[b]{5}{*}{ Parameters/variables } & \multirow[t]{5}{*}{ SW620 } & \multicolumn{2}{|c|}{ SW620 } & \multirow[b]{5}{*}{ P-value ${ }^{a}$} \\
\hline & & \multicolumn{2}{|c|}{ Oligomycin $\mathrm{A}(\mu \mathrm{g} / \mathrm{ml})$} & \\
\hline & & 5 & 10 & \\
\hline & & \multicolumn{2}{|c|}{ Duration (h) } & \\
\hline & & 24 & 24 & \\
\hline \multicolumn{5}{|c|}{ Oxygen consumption rate $(\mathrm{OCR})\left(\mathrm{nmol} / \mathrm{min} / 10^{6}\right.$ cells $)$} \\
\hline \multicolumn{5}{|l|}{ Respiratory substrate } \\
\hline Succinate-supported & $1.85 \pm 0.11$ & $1.02 \pm 0.01$ & $1.04 \pm 0.15$ & 0.112 \\
\hline ADP-stimulated & $3.41 \pm 0.02$ & $1.20 \pm 0.14$ & $1.09 \pm 0.18$ & 0.047 \\
\hline Respiratory control ratio (RCR) & $1.85 \pm 0.09$ & $1.18 \pm 0.13$ & $1.05 \pm 0.02$ & 0.017 \\
\hline \multicolumn{5}{|l|}{ Transwell assay (cells/field) } \\
\hline Invasion & $84.6 \pm 6.9$ & $43.9 \pm 5.8$ & $30.5 \pm 3.5$ & 0.017 \\
\hline
\end{tabular}

OA at $10 \mu \mathrm{g} / \mathrm{ml}$ for $48 \mathrm{~h}(\mathrm{SW} 620 \mathrm{OA}-1048 \mathrm{~h}, 90.1 \pm 8.2 \%$,

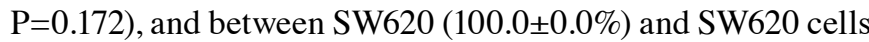
treated with OA at $20 \mu \mathrm{g} / \mathrm{ml}$ for $24 \mathrm{~h}$ (SW620 OA-20 $24 \mathrm{~h}$, $80.4 \pm 17.4 \%, \mathrm{P}=0.191)$. However, SW620 cells $(100.0 \pm 0.0 \%)$ had a significantly higher cell viability than did SW620 cells treated with OA at $20 \mu \mathrm{g} / \mathrm{ml}$ for $48 \mathrm{~h}$ (SW620 OA-20 $48 \mathrm{~h}$, $64.7 \pm 5.9 \%, P=0.009)$. In light of these findings, we did not perform the comparison for SW620 cells treated with OA at $20 \mu \mathrm{g} / \mathrm{ml}$ for $48 \mathrm{~h}$.

In the analysis of the caspase 3 activity (Fig. 3B), we found

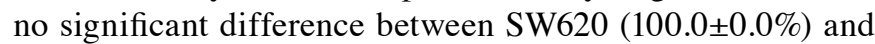
SW620 treated with OA at $10 \mu \mathrm{g} / \mathrm{ml}$ for $24 \mathrm{~h}$ (SW620 OA-10 $24 \mathrm{~h}, 121.7 \pm 7.5 \%, \mathrm{P}=0.152)$, between SW620 (100.0 $\pm 0.0 \%)$ and SW620 treated with OA at $10 \mu \mathrm{g} / \mathrm{ml}$ for $48 \mathrm{~h}$ (SW620 OA-10 $48 \mathrm{~h}, 131.0 \pm 6.2 \%, \mathrm{P}=0.089)$ and between SW620 $(100.0 \pm 0.0 \%)$ and SW620 cells treated with OA at $20 \mu \mathrm{g} / \mathrm{ml}$ for $24 \mathrm{~h}$ (SW620 OA-20 $24 \mathrm{~h}, 109.4 \pm 8.6 \%, \mathrm{P}=0.362$ ). However, these values were all much lower than those of SW620 cells treated with STS $(343.7 \pm 12.5 \%, \mathrm{P}<0.05)$.
As shown in Table IV, from SW620 to SW620 cells treated with $\mathrm{OA}$ at 5 and $10 \mu \mathrm{g} / \mathrm{ml}$ for $24 \mathrm{~h}$, there were progressive decreases in ADP-stimulated OCR (3.41 \pm 0.02 vs. $1.20 \pm 0.14$ vs. $1.09 \pm 0.18, \mathrm{P}=0.047)$ and $\mathrm{RCR}(1.85 \pm 0.09$ vs. $1.18 \pm 0.13$ vs. $1.05 \pm 0.02, \mathrm{P}=0.017)$ of succinate-supported respiration and Transwell invasion activity of SW620 cells (84.6 \pm 6.9 vs. $43.9 \pm 5.8$ vs. $30.5 \pm 3.5, \mathrm{P}=0.017)$.

From SW620 to SW620 cells treated with OA at $10 \mu \mathrm{g} / \mathrm{ml}$ for $24 \mathrm{~h}$ and further treatment of SW620 with OA at $10 \mu \mathrm{g} / \mathrm{ml}$ for $48 \mathrm{~h}$, we found progressive increases in the lactate production rate $(140.6 \pm 6.4$ vs. $179.5 \pm 22.2$ vs. $212.1 \pm 1.6, \mathrm{P}=0.017)$, and intracellular levels of $\mathrm{H}_{2} \mathrm{O}_{2}(0.59 \pm 0.01$ vs. $0.77 \pm 0.03$ vs. $0.81 \pm 0.07, \mathrm{P}=0.047)$ and $\mathrm{O}_{2}^{-\bullet}(0.68 \pm 0.01$ vs. $0.85 \pm 0.02$ vs. $0.88 \pm 0.03, \mathrm{P}=0.026$ ) (Table $\mathrm{V}$ ). No significant differences in the lactate production rate $(206.5 \pm 15.8$ vs. $212.1 \pm 1.6, \mathrm{P}=1.000)$, the intracellular levels of $\mathrm{H}_{2} \mathrm{O}_{2}(1.00 \pm 0.00$ vs. $0.81 \pm 0.07$, $\mathrm{P}=0.333)$ and $\mathrm{O}_{2}^{-\bullet}(1.00 \pm 0.00$ vs. $0.88 \pm 0.03, \mathrm{P}=0.333)$ were found between SW480 and SW620 cells after treatment with $\mathrm{OA}$ at $10 \mu \mathrm{g} / \mathrm{ml}$ for $48 \mathrm{~h}$ (Table V). 


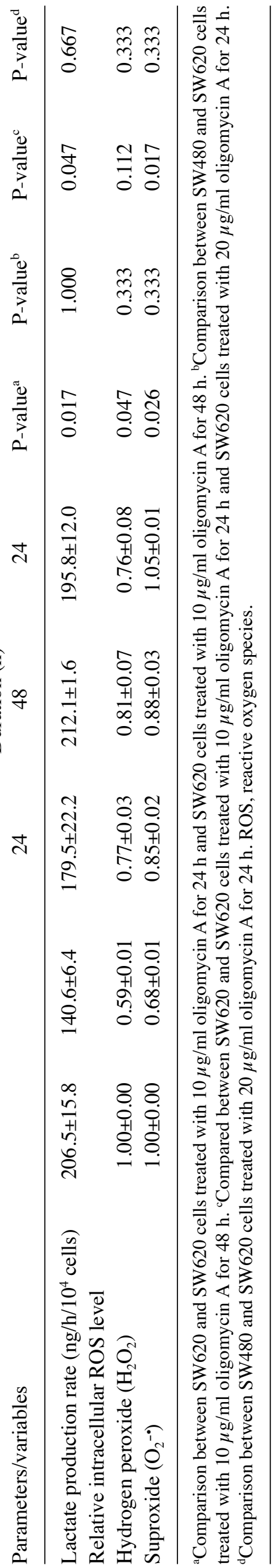

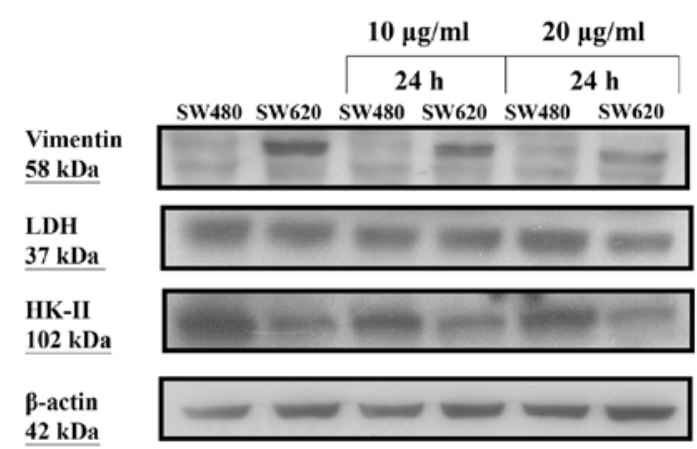

Figure 4. Protein expression levels of glycolytic enzymes HK-II and LDH were stable while EMT marker vimentin was progressively decreased in SW620 cells after treatment for $24 \mathrm{~h}$ with oligomycin A (OA) at 10 and $20 \mu \mathrm{g} / \mathrm{ml}$, respectively. However, no significant changes were noted in SW480 cells treated with OA. HK-II, hexokinase II; LDH, lactate dehydrogenase.

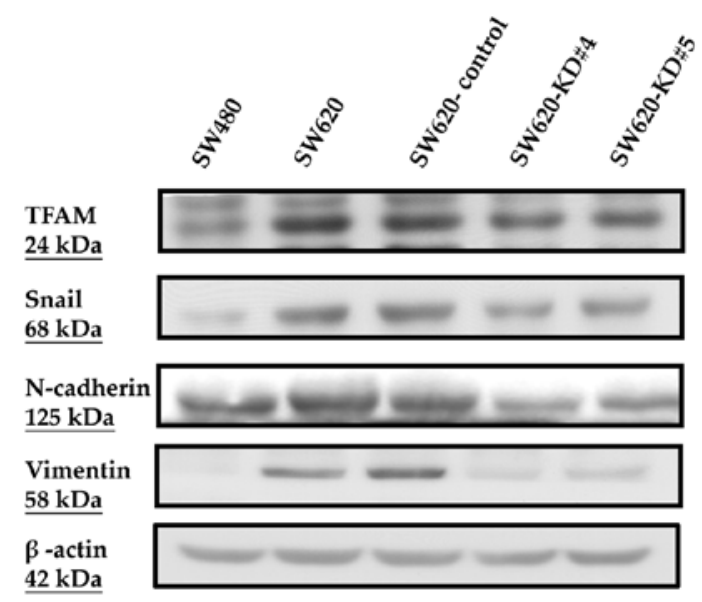

Figure 5. Decrease in the protein expression levels of TFAM and EMT markers Snail, N-cadherin and vimentin after knockdown of TFAM in SW620 cells. TFAM, mitochondrial transcriptional factor A.

From SW620 to SW620 cells treated with OA at 10 and $20 \mu \mathrm{g} / \mathrm{ml}$ for $24 \mathrm{~h}$, progressive increases in the lactate production rate $(140.6 \pm 6.4$ vs. $179.5 \pm 22.2$ vs. $195.8 \pm 12.0, \mathrm{P}=0.047)$ and intracellular level of the $\mathrm{O}_{2}^{-\bullet}(0.68 \pm 0.01$ vs. $0.85 \pm 0.02$ vs. $1.05 \pm 0.01, \mathrm{P}=0.017$ ) were noted (Table V). There were no significant differences in the lactate production rate (206.5 \pm 15.8 vs. $195.8 \pm 12.0, \mathrm{P}=0.667)$, and intracellular level of $\mathrm{O}_{2}{ }^{-\bullet}(1.00 \pm 0.00$ vs. $1.05 \pm 0.01, \mathrm{P}=0.333)$ between $\mathrm{SW} 480$ and SW620 cells treated with OA at $20 \mu \mathrm{g} / \mathrm{ml}$ for $24 \mathrm{~h}$ (Table V).

After treatment of SW480 and SW620 cells with OA at 10 and $20 \mu \mathrm{g} / \mathrm{ml}$ for $24 \mathrm{~h}$, respectively, we found no obvious changes in the protein expression levels of glycolytic enzymes including HK-II and LDH. However, the protein expression level of vimentin was decreased in SW620 cells, but unchanged in SW480 cells (Fig. 4).

Alterations in metabolic profiles, ROS levels and invasion activity after knockdown of TFAM in SW620 cells. Between the parental SW620 and the SW620-Control cells, there were no obvious differences in the protein expression levels of TFAM, Snail, N-cadherin and vimentin (Fig. 5), in mRNA expression levels of TFAM $(2.88 \pm 0.05$ vs. $2.81 \pm 0.02$, $\mathrm{P}=0.122)$ and mtDNA copy numbers $(2.27 \pm 0.13$ vs. $2.21 \pm 0.13$, 


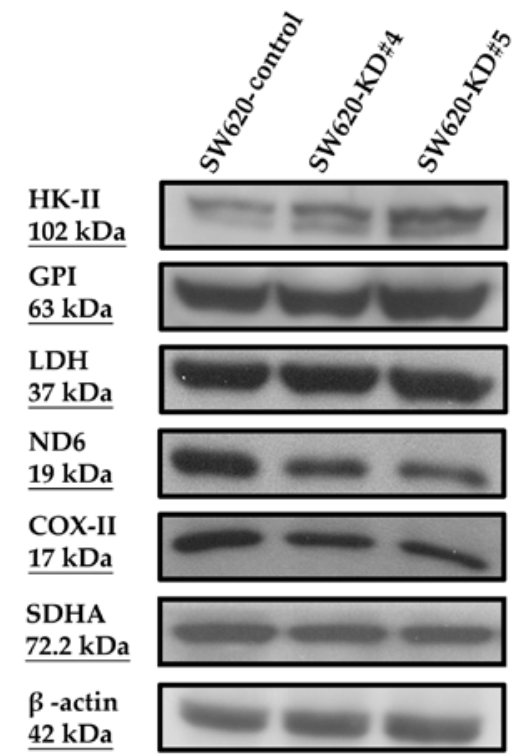

Figure 6. A decrease in the expression levels of mtDNA-encoded proteins ND6 and COX-II without a change in nDNA-encoded SDHA, no change in glycolysis-related enzymes LDH and GPI but an increase in HK-II were noted in the SW620 cells following knockdown of TFAM. ND6, mtDNA-encoded NADH dehydrogenase subunit 6; COX-II, mtDNA-encoded, cytochrome $c$ oxidase subunit II; SDHA, nDNA-encoded, SDHA, succinate dehydrogenase complex flavoprotein subunit A; HK-II, hexokinase II; GPI, glucose 6-phosphate isomerase; $\mathrm{LDH}$, lactate dehydrogenase.

$\mathrm{P}=0.669$ ) (Table VI). The consequences of TFAM knockdown were evaluated and compared between the SW620-Control and SW620-KD\#4 as well as between the SW620-Control and SW620-KD\#5 cells, respectively. Compared to the SW620-Control, both SW620-KD\#4 and SW620-KD\#5 cells had lower protein levels of TFAM, Snail, N-cadherin and vimentin (Fig. 5), a lower mRNA level of TFAM $(1.81 \pm 0.03$ vs. $2.81 \pm 0.02, \mathrm{P}<0.001 ; 1.62 \pm 0.04$ vs. $2.81 \pm 0.02, \mathrm{P}<0.001)$ and lower mtDNA copy number $(1.40 \pm 0.18$ vs. $2.21 \pm 0.13$, $\mathrm{P}=0.036 ; 1.00 \pm 0.10$ vs. $2.21 \pm 0.13, \mathrm{P}=0.009$ ) (Table VI). Both SW620-KD\#4 and SW620-KD\#5 cells had lower protein expression levels of mtDNA-encoded ND6 and COX-II, but similar nDNA-encoded SDHA (Fig. 6), and lower ADP-stimulated OCR $(3.78 \pm 0.13$ vs. $5.61 \pm 0.01, \mathrm{P}=0.002$; $3.50 \pm 0.14$ vs. $5.61 \pm 0.01, \mathrm{P}=0.002)$ and $\mathrm{RCR}(2.02 \pm 0.05$ vs $2.67 \pm 0.11, \mathrm{P}=0.015 ; 1.96 \pm 0.04$ vs. $2.67 \pm 0.11, \mathrm{P}=0.012$ ) values of succinate-supported respiration than did the SW620-Control cells (Table VI). In contrast, both SW620-KD\#4 and SW620-KD\#5 cells had higher protein level of HK-II (Fig. 6) and higher lactate production rate $(130.4 \pm 6.1$ vs. $103.1 \pm 2.7$, $\mathrm{P}=0.002 ; 159.4 \pm 4.9$ vs. $103.1 \pm 2.7, \mathrm{P}<0.001)$ (Table VI) than did the SW620-Control cells. Both SW620-KD\#4 and SW620-KD\#5 cells had higher intracellular levels of $\mathrm{O}_{2}^{-\bullet}$ $(1.65 \pm 0.01$ vs. $1.00 \pm 0.00, \mathrm{P}=0.010 ; 1.67 \pm 0.02$ vs. $1.00 \pm 0.00$, $\mathrm{P}<0.001)$ and $\mathrm{H}_{2} \mathrm{O}_{2}(1.57 \pm 0.10$ vs. $1.00 \pm 0.00, \mathrm{P}=0.036$; $1.73 \pm 0.10$ vs. $1.00 \pm 0.00, \mathrm{P}=0.024)$, but had lower Transwell invasion activity $(94.0 \pm 6.2$ vs. $209.9 \pm 33.6, \mathrm{P}=0.041 ; 80.7 \pm 4.8$ vs. $209.9 \pm 33.6, \mathrm{P}=0.024)$ when compared with the SW620Control (Table VI). However, the protein expression levels of GPI and LDH in the SW620-KD\#4 and SW620-KD\#5 cells were not significantly different from those of the SW620Control cells (Fig. 6).

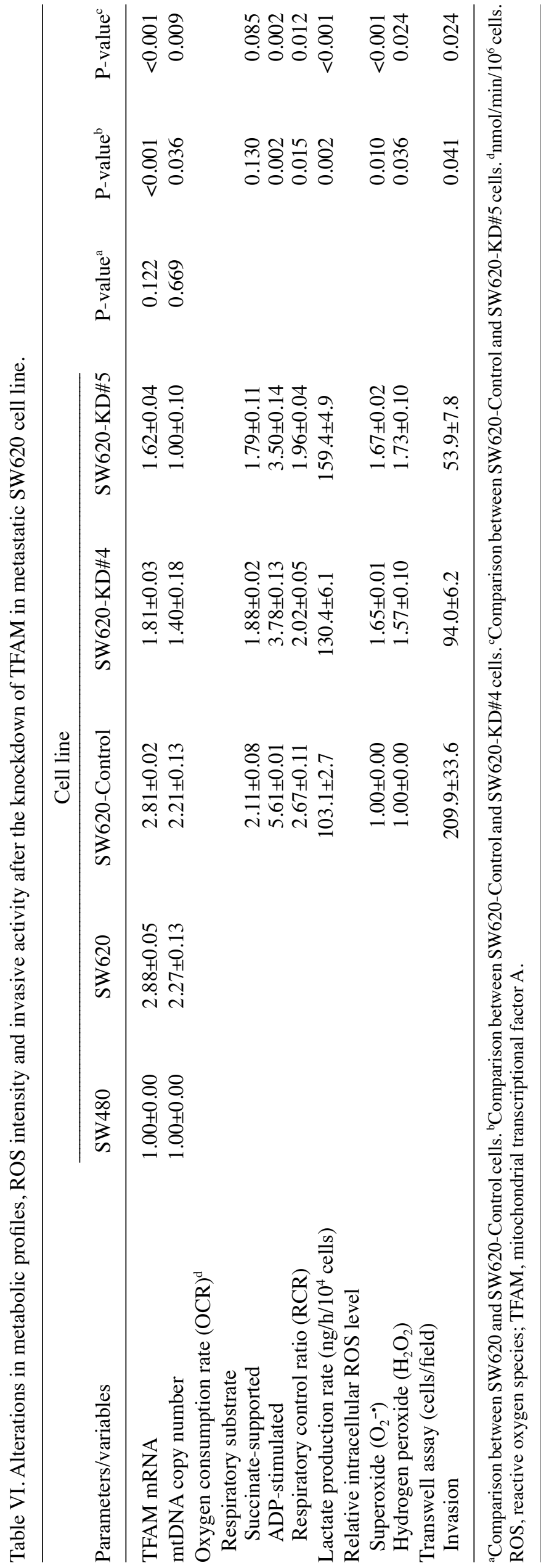


Table VII. Relationships between the clinical parameters and the alteration of mtDNA copy ratios in CRC patients.

\begin{tabular}{lcc}
\hline Parameters & mtDNA copy ratio & P-value \\
\hline Age (years) & & 0.462 \\
$>65(\mathrm{n}=11)$ & $1.30 \pm 1.27$ & \\
$\leq 65(\mathrm{n}=22)$ & $1.07 \pm 0.44$ & \\
Sex & & 0.510 \\
Male ( $\mathrm{n}=22)$ & $1.01 \pm 0.49$ & \\
Female (n=11) & $1.42 \pm 1.20$ & \\
Pathological findings & & \\
T-status & & \\
T1 (n=4) & $0.64 \pm 0.32$ & \\
T2/T3/T4 (n=29) & $1.22 \pm 0.83$ & \\
N status & & \\
N(-) (n=16) & $1.00 \pm 0.56$ & \\
N $(+)(n=17)$ & $1.29 \pm 0.97$ & \\
M status & & \\
M0 (n=32) & $1.15 \pm 0.82$ & \\
M1 (n=1) & $1.05 \pm 0.00$ & \\
Tumor length (cm) & & \\
$\leq 2(n=8)$ & $0.84 \pm 0.34$ & \\
$>2(n=25)$ & $1.25 \pm 0.89$ & \\
\hline
\end{tabular}

mtDNA copy ratio was determined as mtDNA copy number of the tumor part/mtDNA copy number of paired non-tumor part. CRC, colorectal cancer.

Clinical parameters and mtDNA copy ratio. The relationships between the clinical parameters and the mtDNA copy ratios in the tumor tissues of CRC patients are presented in Table VII. We found that deeper tumor invasion beyond the submucosa layer (T2/T3/T4 vs. T1; $1.22 \pm 0.83$ vs. $0.64 \pm 0.32, \mathrm{P}=0.025)$ and longer tumor length ( $>2$ vs. $\leq 2 \mathrm{~cm} ; 1.25 \pm 0.89$ vs. $0.84 \pm 0.34$, $\mathrm{P}=0.069)$ were associated with a higher mtDNA copy ratio in the tumor tissues of the CRC patients examined.

\section{Discussion}

Phenotypically, SW620 cells were found to have a higher Transwell migration activity than do SW480 cells. Biologically, SW620 cells exhibited higher expression of mitochondrial biogenesis-related proteins, higher OCR and higher expression of EMT markers, but lower ROS production, lower glycolytic enzyme and lower lactate production rate than SW480 cells (Table III and Fig. 1). Furthermore, decreases in Transwell migration activity and protein expression of EMT markers were observed in the SW620 cells presenting with suppressed mitochondrial function induced by OA treatment or TFAM knockdown (Figs. 4 and 5; Tables IV and VI). Clinicopathologically, the colorectal cancer (CRC) tumors that invaded beyond the submucosa layer or that had a longer tumor length, had higher mtDNA copy ratios (Table VII). These findings substantiate the notion that suppressed mitochondrial function or low mtDNA copy number may contribute to a decrease in the invasion activity of CRC cells. However, these findings are different from the well-known Warburg effect. Thus, further studies are warranted using more tumor specimens of CRC patients at different clinical stages, different CRC cell lines, or using other agents to suppress mitochondrial function in the near future.

Impairment or suppression of mitochondria in human cancers was first described by Dr Warburg based on his finding of enhanced glycolysis in cancer tissue even when the oxygen supply is sufficient $(4,6)$. As a result, some cancer researchers claimed that mitochondrial dysfunction may be involved in the carcinogenesis and progression of cancers (51-54). However, there are conflicting results. During the past two decades, alteration of mitochondrial biogenesis has been evaluated and discussed in many human cancers $(15,23,55,56)$. A decrease in mtDNA copy number, an increase in oxidative mtDNA damage or decreases in the activities of respiratory enzyme complexes have been observed in human lung, gastric and breast cancer, renal cell carcinoma and esophageal cancer $(26,28,57,58)$. On the contrary, increases in mtDNA copy number or mitochondrial function were found in esophageal cancer or head and neck cancer during carcinogenesis or progression of cancers $(18,21,22,59)$. With regard to the mitochondrial alterations in human CRC, some reseachers have demonstrated an increase in mtDNA copy number or increased expression of mtDNA-encoded ND2 (60-63). In contrast, some showed a decrease in mtDNA copy number, a decrease in mitochondrial function or the presence of mDNA mutation (64-66). Whether mitochondrial biogenesis is suppressed, amplified or dysfunctional in human cancers, including $\mathrm{CRC}$, has remained a puzzle.

Recently, the concept of glucose metabolic switch (the Warburg effect) has been associated with metabolic reprogramming in cancer mitochondria. In other words, the consideration of maximal bioenergetic demand has been shifted to the regulation of both biosynthetic and energetic demands (67-69). For a given cancer cell, it needs an ATP supply, but also carbohydrate, lipid and protein synthesis to support cancer growth. After glucose uptake and glycolysis, PDH may convert pyruvate to acetyl-CoA to enter the Krebs cycle in the mitochondria. The Krebs cycle can offer high energy intermediates, NADH or $\mathrm{FADH}_{2}$, for subsequent electron transport and ATP production and can offer citrate, which can be exported from the mitochondria to the cytosol, to re-form acetyl-CoA for lipid synthesis in the cytosol. PDH plays an important role in metabolic reprogramming of human cancer. Intriguingly, Koukourakis et al demonstrated that when lung tissues of cancer patients exhibited decreased PDH expression (suggesting the shutdown of oxidative metabolism or metabolic reprogramming) and decreased LDH5 expression (suggesting a shutdown of Warburg effect and glucose metabolic switch), they had the best prognosis (70). This explains why SW620 cells harboring higher protein levels of PDH and TFAM expression, indicating a higher biosynthetic and energetic activity, had a higher Transwell migration activity than did the SW480 cells (Figs. 1 and 2). Indeed, several studies have suggested that most cancer mitochondria are not impaired in executing oxidative phosphorylation. Nevertheless, they are reprogrammed to meet the need of biosynthesis of macromolecules and growth of human cancer (67-73). Furthermore, 
the associations among EMT, stemness properties and mitochondrial metabolic reprogramming have received great attention of cancer research scientists (74-76). Mitochondria have remained the main powerhouse of human cancers, and high mitochondrial function may confer high invasive property in human cancer cells, as demonstrated in the present study and our previous observations in esophageal cancer cell lines $(22,73)$.

Whether mitochondrial function does affect the invasion activity of CRC cells, suppression of mitochondrial function of SW620 cells could confer SW620 cells a phenotype with lower invasion activity. After treatments of cancer cells with 5, 10 and $20 \mu \mathrm{g} / \mathrm{ml}$ of OA, we demonstrated that the OA-treated SW620 cells exhibited decreased Transwell migration activity and decreased vimentin expression, increased ROS production and increased lactate fermentation which mimicked SW480 cells (Fig. 4; Tables IV and V). OA is commonly used to suppress mitochondrial production of ATP. Different concentrations of OA have been used, including $0.5 \mu \mathrm{g} / \mathrm{ml}$ for HepG2 cells (77), 2.5, 5, 10 and $25 \mu \mathrm{g} / \mathrm{ml}$ for human chondrocytes (40), $10 \mu \mathrm{g} / \mathrm{ml}$ for adipose tissue cells (38), and $15 \mu \mathrm{g} / \mathrm{ml}$ for SKBR3 and 4T1 breast cancer cells (39). The concentrations of 5, 10 and $20 \mu \mathrm{g} / \mathrm{ml}$ of OA were thus used in the present study.

Such a high OA concentrations in the present study did confer SW620 cells the ability to exhibit some characteristics similar to SW480 cells (Tables IV and V), but did not cause an obvious decrease in cell viability or increase in caspase 3 activity in the SW620 cells (Fig. 3A and B). However, it seemed to markedly suppress the mitochondrial function in SW620 cells (Table IV). This indicates a near-complete suppression of mitochondrial function of SW620 cells, which is not applicable in a physiological condition. As a result, we further conducted the knockdown of TFAM in SW620 cells to test our hypothesis. The TFAM-knockdown SW620 cells did display lower RCR, but not as low as the results following OA treatment (Tables IV and VI). The TFAM-knockdown SW620 cells expressed lower levels of mtDNA-encoded polypeptides (ND6 and COX-II, Fig. 6), but increased intracellular ROS production and a lactate production rate (Table VI) and HK-II protein expression (Fig. 6). Subsequently, the TFAM-knockdown SW620 cells expressed lower protein levels of EMT markers including Snail, N-cadherin and vimentin (Fig. 5) and lower Transwell invasion activity (Table VI). It is worth mentioning that SW620-KD\#4 and SW620-KD\#5 cells did express lower mtDNA-encoded ND6 and COX-II without obvious alteration in nDNA-encoded SDHA (Fig. 6), which have convinced us that these are caused by the selective effect of TFMA knockdown rather than off-target effects. However, some differences existed between the SW620-Control and the parental SW620 cells, including RCR and Transwell invasion activity. The possible effects of scramble Luc-vector, the facilitation of Lipofectamine 2000, and the addition of puromycin for clone selection may account for these differences. On the contrary, we tried to further evaluate the effects of overexpression of TFAM on the OCR, ROS, EMT markers, and invasion of SW480 and SW620 cells to test our hypothesis. We found that SW480 with TFAM overexpression did show increased expression of COX-II, Snail and vimentin (data not shown). The preliminary data indicated that mitochondrial function may serve an important role in the invasiveness of human CRC cells. More investigations, either in vitro or ex vivo studies, are needed in the near future to generate a clear picture of mitochondrial function in the invasion and progression of human cancers.

The novel role of TFAM in human colon cancer has been a hot research topic. Studies have shown that p53 increases mtDNA copy number via upregulation of TFAM, and a high level of TFAM expression was found to be associated with a poor prognosis in CRC patients $(60,78,79)$. Some investigators further claimed that TFAM may be involved in the carcinogenesis of CRCs. TFAM and mitochondrial function in human CRCs deserve further studies in the future.

A difference in ROS production was also observed between SW480 and SW620 CRC cells, and between SW620 and SW620 cells with suppressed mitochondrial function through OA treatment or TFAM knockdown (Tables III, V and VI). Several recent studies suggest that mitochondria can generate some retrograding signals, ROS included, for cellular adaptation or cancer invasion (80-82). The endogenous ROS generated from mitochondria through electron leak can cross the mitochondrial membrane to regulate several proteins, transcriptional factors and transcriptional co-activators, e.g., PCG- $1 \alpha$ as demonstrated in the present study (Table III) $(83,84)$. PCG-1 $\alpha$ has also been shown to play an important role in the regulation of TFAM (11). Abrupt production of ROS may be hazardous to living cells through the triggering of necrosis or apoptosis. Moderate levels of ROS may act as regulatory mediators in signaling processes. Sustained increase in the production of ROS is implicated in the pathogenesis of cancer and other diseases (85-87). However, the suitable levels or thresholds of mitochondrial ROS for cancer carcinogenesis, progression or invasion were not clearly demonstrated in the present study and have remained unclear $(88,89)$.

Another important finding of the present study is amplified lactate fermentation of SW620 cells with suppressed mitochondrial function, and the difference in glycolysis between SW480 and SW620 cells (Tables III, V and VI). Since similar ATP levels were found in SW480 and SW620 cells, it seems reasonable to conjecture that the increase in lactate fermentation is compensated for the defects in mitochondrial function as described by Warburg (4-6). However, some researchers suggest that lactate fermentation from amplified glycolysis may confer several advantages for carcinogenesis, proliferation and progression of cancers by providing precursors for DNA/RNA synthesis and eradicating ROS by NADPH produced from the pentose phosphate pathway (PPP) $(52,89,90)$. The PPP is an offshoot pathway parallel to glycolysis that generates NADPH and 5 -carbon sugars for biosynthesis of nucleotides $(52,89)$.

Recent studies indicate that proto-oncogenes, tumorsuppressor genes and specific signaling pathways may participate in the regulation of metabolic reprogramming or increase of glycolysis, including PI3K/Akt/mTOR1 and HIF-1/PDK1/PDH pathways, c-myc oncogene activation, and mutant p53 tumorsuppressor gene $(5,80,91-95)$. However, the detail mechanism involved in CRC invasion deserves future study.

Regarding the difference between cancer cell invasion activity between SW480 and SW620 cells, some controversies exist. We and some researchers have demonstrated that SW620 cells have a higher invasion activity than SW480 cells $(34,96,97)$. On the contrary, higher invasion activity 
of SW480 cells was observed in other studies $(50,98,99)$. Differences in the culture medium, cell migration assay, and activation of signaling pathways may account for these differences. The tumor microenvironment seems to be another important issue in cancer cell adaptation to different cancer invasion phenotypes (100).

In summary, the above-mentioned findings suggest that a sufficient supply of ATP by mitochondrial respiration and oxidative phosphorylation is essential for migration and invasion of CRC cells. Metabolic reprogramming, amplified glycolysis and mitochondrial retrograde signaling are advantageous for cancer cells to achieve effective adaption to the microenvironment. However, the checkpoint and mechanism with which to trigger metabolic reprogramming and cancer invasion have remained a puzzle. We speculate that this type of metabolic plasticity may be a signature of malignant cancer cells, which may explain the failure of many anticancer therapies.

\section{Acknowledgements}

The present study was supported by grants from the Ministry of Science and Technology, Executive Yuan, Taiwan (MOST1042320-B-715-006-MY2, MOST104-2627-B-715-002 and MOST105-2627-M-715-001-).

\section{References}

1. Puppa G, Sonzogni A, Colombari R and Pelosi G: TNM staging system of colorectal carcinoma: A critical appraisal of challenging issues. Arch Pathol Lab Med 134: 837-852, 2010.

2. Hsu CC, Tseng LM and Lee HC: Role of mitochondrial dysfunction in cancer progression. Exp Biol Med 241: 1281-1295, 2016.

3. Fearon ER: Molecular genetics of colorectal cancer. Annu Rev Pathol 6: 479-507, 2011

4. Warburg $\mathrm{O}$, Wind $\mathrm{F}$ and Negelein $\mathrm{E}$ : The metabolism of tumors in the body. J Gen Physiol 8: 519-530, 1927.

5. Kim JW and Dang CV: Cancer's molecular sweet tooth and the Warburg effect. Cancer Res 66: 8927-8930, 2006.

6. Warburg O: On the origin of cancer cells. Science 123: 309-314, 1956.

7. Bratic I and Trifunovic A: Mitochondrial energy metabolism and ageing. Biochim Biophys Acta 797: 961-967, 2010.

8. Gilkerson R, Bravo L, Garcia I, Gaytan N, Herrera A, Maldonado A and Quintanilla B: The mitochondrial nucleoid: Integrating mitochondrial DNA into cellular homeostasis. Cold Spring Harb Perspect Biol 5: a011080, 2013.

9. Kaniak-Golik A and Skoneczna A: Mitochondria-nucleus network for genome stability. Free Radic Biol Med 82: 73-104, 2015.

10. Baker MJ, Frazier AE, Gulbis JM and Ryan MT: Mitochondrial protein-import machinery: Correlating structure with function. Trends Cell Biol 17: 456-464, 2007.

11. Lee HC and Wei YH: Mitochondrial biogenesis and mitochondrial DNA maintenance of mammalian cells under oxidative stress. Int J Biochem Cell Biol 37: 822-834, 2005.

12. Asin-Cayuela J and Gustafsson CM: Mitochondrial transcription and its regulation in mammalian cells. Trends Biochem Sci 32 $111-117,2007$.

13. Moraes CT: What regulates mitochondrial DNA copy number in animal cells? Trends Genet 17: 199-205, 2001.

14. Boland ML, Chourasia AH and Macleod KF: Mitochondrial dysfunction in cancer. Front Oncol 3: 292, 2013.

15. Lin CS and Wang LS: Mitochondrial DNA instability in human cancers. Formos J Surg 46: 71-75, 2013.

16. Lee $\mathrm{CH}$ and $\mathrm{Yu} \mathrm{HS}$ : Role of mitochondria, ROS, and DNA damage in arsenic induced carcinogenesis. Front Biosci 8: 312-320, 2016

17. Lee CH, Wu SB, Hong CH, Liao WT, Wu CY, Chen GS, Wei YH and Yu HS: Aberrant cell proliferation by enhanced mitochondrial biogenesis via mtTFA in arsenical skin cancers. Am J Pathol 178: 2066-2076, 2011.
18. Kim MM, Clinger JD, Masayesva BG, Ha PK, Zahurak ML, Westra WH and Califano JA: Mitochondrial DNA quantity increases with histopathologic grade in premalignant and malignant head and neck lesions. Clin Cancer Res 10: 8512-8515, 2004.

19. Yu M, Shi Y, Wei X, Yang Y, Zhou Y, Hao X, Zhang N and Niu R: Depletion of mitochondrial DNA by ethidium bromide treatment inhibits the proliferation and tumorigenesis of T47D human breast cancer cells. Toxicol Lett 170: 83-93, 2007.

20. Lin CS, Chang SC, Ou LH, Chen CM, Hsieh SS, Chung YP, King KL, Lin SL and Wei YH: Mitochondrial DNA alterations correlate with the pathological status and the immunological ER, PR, HER-2/neu, p53 and Ki-67 expression in breast invasive ductal carcinoma. Oncol Rep 33: 2924-2934, 2015.

21. Lin CS, Chang SC, Wang LS, Chou TY, Hsu WH, Wu YC and Wei YH: The role of mitochondrial DNA alterations in esophageal squamous cell carcinomas. J Thorac Cardiovasc Surg 139: 189-197 e184, 2010.

22. Lin CS, Lee HT, Lee SY, Shen YA, Wang LS, Chen YJ and Wei YH: High mitochondrial DNA copy number and bioenergetic function are associated with tumor invasion of esophageal squamous cell carcinoma cell lines. Int J Mol Sci 13: 11228-11246, 2012.

23. Lee HC and Wei YH: Mitochondrial DNA instability and metabolic shift in human cancers. Int J Mol Sci 10: 674-701, 2009.

24. Roberts ER and Thomas KJ: The role of mitochondria in the development and progression of lung cancer. Comput Struct Biotechnol J 6: e201303019, 2013.

25. Lin CS, Wang LS, Tsai CM and Wei YH: Low copy number and low oxidative damage of mitochondrial DNA are associated with tumor progression in lung cancer tissues after neoadjuvant chemotherapy. Interact Cardiovasc Thorac Surg 7: 954-958, 2008.

26. Simonnet H, Alazard N,Pfeiffer K, Gallou C, Béroud C, Demont J, Bouvier R, Schägger $\mathrm{H}$ and Godinot $\mathrm{C}$ : Low mitochondrial respiratory chain content correlates with tumor aggressiveness in renal cell carcinoma. Carcinogenesis 23: 759-768, 2002.

27. Lin CS, Lee HT, Lee MH, Pan SC, Ke CY, Chiu AW and Wei YH: Role of mitochondrial DNA copy number alteration in human renal cell carcinoma. Int J Mol Sci 17: E814, 2016.

28. Wu CW, Yin PH, Hung WY, Li AF, Li SH, Chi CW, Wei YH and Lee HC: Mitochondrial DNA mutations and mitochondrial DNA depletion in gastric cancer. Genes Chromosomes Cancer 44: 19-28, 2005.

29. Lee YK, Woo HG and Yoon G: Mitochondrial defect-responsive gene signature in liver-cancer progression. BMB Rep 48: 597-598, 2015.

30. Yin PH, Lee HC, Chau GY, Wu YT, Li SH, Lui WY, Wei YH, Liu TY and Chi CW: Alteration of the copy number and deletion of mitochondrial DNA in human hepatocellular carcinoma. Br J Cancer 90: 2390-2396, 2004.

31. Toki N, Kagami S, Kurita T, Kawagoe T, Matsuura Y, Hachisuga T, Matsuyama A, Hashimoto H, Izumi $H$ and Kohno K: Expression of mitochondrial transcription factor A in endometrial carcinomas: Clinicopathologic correlations and prognostic significance. Virchows Arch 456: 387-393, 2010.

32. Singh KP, Kumari R, Treas J and DuMond JW: Chronic exposure to arsenic causes increased cell survival, DNA damage, and increased expression of mitochondrial transcription factor $\mathrm{A}$ $(m t T F A)$ in human prostate epithelial cells. Chem Res Toxicol 24: 340-349, 2011.

33. Mo M, Peng F, Wang L, Peng L, Lan G and Yu S: Roles of mitochondrial transcription factor A and microRNA-590-3p in the development of bladder cancer. Oncol Lett 6: 617-623, 2013.

34. Hewitt RE, McMarlin A, Kleiner D, Wersto R, Martin P, Tsokos M, Stamp GW and Stetler-Stevenson WG: Validation of a model of colon cancer progression. J Pathol 192: 446-454, 2000.

35. Leibovitz A, Stinson JC, McCombs WB III, McCoy CE, Mazur KC and Mabry ND: Classification of human colorectal adenocarcinoma cell lines. Cancer Res 36: 4562-4569, 1976.

36. Futschik M, Jeffs A, Pattison S, Kasabov N, Sullivan M, Merrie A and Reeve A: Gene expression profiling of metastatic and nonmetastatic colorectal cancer cell lines. Genome Lett 1: 26-34, 2002.

37. Lee CC, Chen WS, Chen CC, Chen LL, Lin YS, Fan CS and Huang TS: TCF12 protein functions as transcriptional repressor of E-cadherin, and its overexpression is correlated with metastasis of colorectal cancer. J Biol Chem 287: 2798-2809, 2012.

38. Wang $\mathrm{CH}$, Wang CC, Huang HC and Wei YH: Mitochondrial dysfunction leads to impairment of insulin sensitivity and adiponectin secretion in adipocytes. FEBS J 280: 1039-1050, 2013 
39. Ma J, Zhang Q, Chen S, Fang B, Yang Q, Chen C, Miele L, Sarkar FH, Xia J and Wang Z: Mitochondrial dysfunction promotes breast cancer cell migration and invasion through HIF1 $\alpha$ accumulation via increased production of reactive oxygen species. PLoS One 8: e69485, 2013.

40. Cillero-Pastor B, Rego-Pérez I, Oreiro N, Fernandez-Lopez C and Blanco FJ: Mitochondrial respiratory chain dysfunction modulates metalloproteases $-1,-3$ and -13 in human normal chondrocytes in culture. BMC Musculoskelet Disord 14: 235, 2013

41. Li C, Wu Z, Liu M, Pazgier M and Lu W: Chemically synthesized human survivin does not inhibit caspase-3. Protein Sci 17: 1624-1629, 2008.

42. Salazar N, Muñoz D, Hoy J and Lokeshwar BL: Use of shRNA for stable suppression of chemokine receptor expression and function in human cancer cell lines. Methods Mol Biol 1172: 209-218, 2014

43. Chen CT, Shih YR, Kuo TK, Lee OK and Wei YH: Coordinated changes of mitochondrial biogenesis and antioxidant enzymes during osteogenic differentiation of human mesenchymal stem cells. Stem Cells 26: 960-968, 2008

44. Clerc P and Polster BM: Investigation of mitochondrial dysfunction by sequential microplate-based respiration measurements from intact and permeabilized neurons. PLoS One 7: e34465, 2012.

45. Wang $\mathrm{CH}$, Chen $\mathrm{YF}, \mathrm{Wu} \mathrm{CY}$, Wu PC, Huang $\mathrm{YL}$, $\mathrm{Kao} \mathrm{CH}$, Lin CH, Kao LS, Tsai TF and Wei YH: Cisd2 modulates the differentiation and functioning of adipocytes by regulating intracellular $\mathrm{Ca}^{2+}$ homeostasis. Hum Mol Genet 23: 4770-4785, 2014.

46. Chou SJ, Tseng WL, Chen CT, Lai YF, Chien CS, Chang YL, Lee HC, Wei YH and Chiou SH: Impaired ROS scavenging system in human induced pluripotent stem cells generated from patients with MERRF syndrome. Sci Rep 6: 23661, 2016.

47. Lee HT, Lin CS, Chen WS, Liao HT, Tsai CY and Wei YH: Leukocyte mitochondrial DNA alteration in systemic lupus erythematosus and its relevance to the susceptibility to lupus nephritis. Int J Mol Sci 13: 8853-8868, 2012.

48. Lee HT, Lin CS, Lee CS, Tsai CY and Wei YH: Increased 8-hydroxy-2'-deoxyguanosine in plasma and decreased mRNA expression of human 8-oxoguanine DNA glycosylase 1, antioxidant enzymes, mitochondrial biogenesis-related proteins and glycolytic enzymes in leucocytes in patients with systemic lupus erythematosus. Clin Exp Immunol 176: 66-77, 2014

49. Livak KJ and Schmittgen TD: Analysis of relative gene expression data using real-time quantitative PCR and the $2^{-\Delta \Delta C}$ method. Methods 25: 402-408, 2001.

50. Kubens BS and Zänker KS: Differences in the migration capacity of primary human colon carcinoma cells (SW480) and their lymph node metastatic derivatives (SW620). Cancer Lett 131: 55-64, 1998.

51. Koppenol WH, Bounds PL and Dang CV: Otto Warburg's contributions to current concepts of cancer metabolism. Nat Rev Cancer 11: 325-337, 2011.

52. Pedersen PL: Warburg, me and Hexokinase 2: Multiple discoveries of key molecular events underlying one of cancers most common phenotypes, the 'Warburg Effect', i.e., elevated glycolysis in the presence of oxygen. J Bioenerg Biomembr 39: 211-222, 2007.

53. Gatenby RA and Gillies RJ: Why do cancers have high aerobic glycolysis? Nat Rev Cancer 4: 891-899, 2004.

54. Lu J, Tan M and Cai Q: The Warburg effect in tumor progression Mitochondrial oxidative metabolism as an anti-metastasis mechanism. Cancer Lett 356: 156-164, 2015.

55. Zong WX, Rabinowitz JD and White E: Mitochondria and Cancer. Mol Cell 61: 667-676, 2016.

56. Verschoor ML, Ungard R, Harbottle A, Jakupciak JP, Parr RL and Singh G: Mitochondria and cancer: Past, present, and future. Biomed Res Int 2013: 612369, 2013.

57. Lee HC, Yin PH, Lin JC, Wu CC, Chen CY, Wu CW, Chi CW, Tam TN and Wei YH: Mitochondrial genome instability and mtDNA depletion in human cancers. Ann NY Acad Sci 1042: 109-122, 2005.

58. Tseng LM, Yin PH, Chi CW, Hsu CY, Wu CW, Lee LM, Wei YH and Lee HC: Mitochondrial DNA mutations and mitochondrial DNA depletion in breast cancer. Genes Chromosomes Cancer 45: 629-638, 2006

59. Jiang WW, Masayesva B, Zahurak M, Carvalho AL, Rosenbaum E, Mambo E, Zhou S, Minhas K, Benoit N, Westra WH, et al: Increased mitochondrial DNA content in saliva associated with head and neck cancer. Clin Cancer Res 11: 2486-2491, 2005.
60. Wen S, Gao J, Zhang L, Zhou H, Fang D and Feng S: p53 increase mitochondrial copy number via up-regulation of mitochondrial transcription factor A in colorectal cancer. Oncotarget 7: 75981-75995, 2016.

61. Gao J, Wen S, Zhou H and Feng S: De-methylation of displacement loop of mitochondrial DNA is associated with increased mitochondrial copy number and nicotinamide adenine dinucleotide subunit 2 expression in colorectal cancer. Mol Med Rep 12: 7033-7038, 2015.

62. Feng S, Xiong L, Ji Z, Cheng W and Yang H: Correlation between increased copy number of mitochondrial DNA and clinicopathological stage in colorectal cancer. Oncol Lett 2: 899-903, 2011.

63. Feng S, Xiong L, Ji Z, Cheng W and Yang H: Correlation between increased ND2 expression and demethylated displacement loop of mtDNA in colorectal cancer. Mol Med Rep 6: 125-130, 2012.

64. van Osch FH, Voets AM, Schouten LJ, Gottschalk RW, Simons CC, van Engeland M, Lentjes MH, van den Brandt PA, Smeets HJ and Weijenberg MP: Mitochondrial DNA copy number in colorectal cancer: Between tissue comparisons, clinicopathological characteristics and survival. Carcinogenesis 36 : $1502-1510,2015$

65. Cui H, Huang P, Wang Z, Zhang Y, Zhang Z, Xu W, Wang X, Han Y and Guo X: Association of decreased mitochondrial DNA content with the progression of colorectal cancer. BMC Cancer 13: 110, 2013.

66. Sanchez-Pino MJ, Moreno P and Navarro A: Mitochondrial dysfunction in human colorectal cancer progression. Front Biosci 12: 1190-1199, 2007.

67. Phan LM, Yeung SC and Lee MH: Cancer metabolic reprogramming: Importance, main features, and potentials for precise targeted anti-cancer therapies. Cancer Biol Med 11: 1-19, 2014.

68. Yoshida GJ: Metabolic reprogramming: The emerging concept and associated therapeutic strategies. J Exp Clin Cancer Res 34: $111,2015$.

69. Ward PS and Thompson CB: Metabolic reprogramming: A cancer hallmark even warburg did not anticipate. Cancer Cell 21: 297-308, 2012

70. Koukourakis MI, Giatromanolaki A, Sivridis E, Gatter KC and Harris AL; Tumor and Angiogenesis Research Group: Pyruvate dehydrogenase and pyruvate dehydrogenase kinase expression in non small cell lung cancer and tumor-associated stroma. Neoplasia 7: 1-6, 2005.

71. Zheng J: Energy metabolism of cancer: Glycolysis versus oxidative phosphorylation (Review). Oncol Lett 4: 1151-1157, 2012.

72. Vyas S, Zaganjor E and Haigis MC: Mitochondria and cancer. Cell 166: 555-566, 2016

73. Ahn CS and Metallo CM: Mitochondria as biosynthetic factories for cancer proliferation. Cancer Metab 3: 1, 2015.

74. Shen YA, Wang CY, Hsieh YT, Chen YJ and Wei YH: Metabolic reprogramming orchestrates cancer stem cell properties in nasopharyngeal carcinoma. Cell Cycle 14: 86-98, 2015.

75. Shen YA, Lin CH, Chi WH, Wang CY, Hsieh YT, Wei YH and Chen YJ: Resveratrol impedes the stemness, epithelial-mesenchymal transition, and metabolic reprogramming of cancer stem cells in nasopharyngeal carcinoma through p53 activation. Evid Based Complement Alternat Med 2013: 590393, 2013.

76. Guha M, Srinivasan S, Ruthel G, Kashina AK, Carstens RP Mendoza A, Khanna C, Van Winkle T and Avadhani NG: Mitochondrial retrograde signaling induces epithelial-mesenchymal transition and generates breast cancer stem cells. Oncogene 33: 5238-5250, 2014.

77. Chang CJ, Yin PH, Yang DM, Wang CH, Hung WY, Chi CW, Wei YH and Lee HC: Mitochondrial dysfunction-induced amphiregulin upregulation mediates chemo-resistance and cell migration in HepG2 cells. Cell Mol Life Sci 66: 1755-1765, 2009.

78. Yoshida Y, Hasegawa J, Nezu R, Kim YK, Hirota M, Kawano K, Izumi $\mathrm{H}$ and Kohno $\mathrm{K}$ : Clinical usefulness of mitochondrial transcription factor A expression as a predictive marker in colorectal cancer patients treated with FOLFOX. Cancer Sci 102: 578-582, 2011.

79. Nakayama Y, Yamauchi M, Minagawa N, Torigoe T, Izumi H, Kohno $\mathrm{K}$ and Yamaguchi K: Clinical significance of mitochondrial transcription factor A expression in patients with colorectal cancer. Oncol Rep 27: 1325-1330, 2012.

80. Barbour JA and Turner N: Mitochondrial stress signaling promotes cellular adaptations. Int J Cell Biol 2014: 156020, 2014.

81. da Cunha FM, Torelli NQ and Kowaltowski AJ: Mitochondrial retrograde signaling: Triggers, pathways, and outcomes. Oxid Med Cell Longev 2015: 482582, 2015. 
82. Guha M and Avadhani NG: Mitochondrial retrograde signaling at the crossroads of tumor bioenergetics, genetics and epigenetics. Mitochondrion 13: 577-591, 2013.

83. Murphy MP: How mitochondria produce reactive oxygen species. Biochem J 417: 1-13, 2009.

84. St-Pierre J, Drori S, Uldry M, Silvaggi JM, Rhee J, Jäger S, Handschin C, Zheng K, Lin J, Yang W, et al: Suppression of reactive oxygen species and neurodegeneration by the PGC-1 transcriptional coactivators. Cell 127: 397-408, 2006.

85. Dröge W: Free radicals in the physiological control of cell function. Physiol Rev 82: 47-95, 2002.

86. Alfadda AA and Sallam RM: Reactive oxygen species in health and disease. J Biomed Biotechnol 2012: 936486, 2012.

87. Eisele HJ, Markart P and Schulz R: Obstructive sleep apnea, oxidative stress, and cardiovascular disease: Evidence from human studies. Oxid Med Cell Longev 2015: 608438, 2015.

88. Sabharwal SS and Schumacker PT: Mitochondrial ROS in cancer: Initiators, amplifiers or an Achilles' heel? Nat Rev Cancer 14: 709-721, 2014

89. Lu F: Reactive oxygen species in cancer, too much or too little? Med Hypotheses 69: 1293-1298, 2007.

90. Kondoh H, Lleonart ME, Gil J, Wang J, Degan P, Peters G, Martinez D, Carnero A and Beach D: Glycolytic enzymes can modulate cellular life span. Cancer Res 65: 177-185, 2005.

91. Li F, Wang Y, Zeller KI, Potter JJ, Wonsey DR, O'Donnell KA, Kim JW, Yustein JT, Lee LA and Dang CV: Myc stimulates nuclearly encoded mitochondrial genes and mitochondrial biogenesis. Mol Cell Biol 25: 6225-6234, 2005.

92. Papandreou I, Cairns RA, Fontana L, Lim AL and Denko NC: HIF-1 mediates adaptation to hypoxia by actively downregulating mitochondrial oxygen consumption. Cell Metab 3: 187-197, 2006.
93. Buzzai M, Bauer DE, Jones RG, Deberardinis RJ Hatzivassiliou G, Elstrom RL and Thompson CB: The glucose dependence of Akt-transformed cells can be reversed by pharmacologic activation of fatty acid beta-oxidation. Oncogene 24 : 4165-4173, 2005.

94. Düvel K, Yecies JL, Menon S, Raman P, Lipovsky AI, Souza AL, Triantafellow E, Ma Q, Gorski R, Cleaver S, et al: Activation of a metabolic gene regulatory network downstream of mTOR complex 1. Mol Cell 39: 171-183, 2010.

95. Fields J, Hanisch JJ, Choi JW and Hwang PM: How does p53 regulate mitochondrial respiration? IUBMB Life 59: 682-684, 2007.

96. Ni J, Jiang Z, Shen L, Gao L, Yu M, Xu X, Zou S, Hua D and Wu S: $\beta 3 \mathrm{GnT} 8$ regulates the metastatic potential of colorectal carcinoma cells by altering the glycosylation of CD147. Oncol Rep 31: 1795-1801, 2014.

97. Cai K, Mulatz K, Ard R, Nguyen T and Gee SH: Increased diacylglycerol kinase $\zeta$ expression in human metastatic colon cancer cells augments Rho GTPase activity and contributes to enhanced invasion. BMC Cancer 14: 208, 2014.

98. Schimanski CC, Schwald S, Simiantonaki N, Jayasinghe C, Gönner U, Wilsberg V, Junginger T, Berger MR, Galle PR and Moehler M: Effect of chemokine receptors CXCR4 and CCR7 on the metastatic behavior of human colorectal cancer. Clin Cancer Res 11: 1743-1750, 2005.

99. Kusakai G, Suzuki A, Ogura T, Miyamoto S, Ochiai A Kaminishi $M$ and Esumi H: ARK5 expression in colorectal cancer and its implications for tumor progression. Am J Pathol 164: 987-995, 2004

100. Friedl P and Alexander S: Cancer invasion and the microenvironment: Plasticity and reciprocity. Cell 147: 992-1009, 2011. 